\section{SOUTH EAST} EUROPE

Jointly for our common future

\section{SNAPOSESE \\ Planning Aggregates Supply}

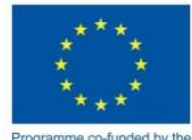

Programme co-funded by the EUROPEAN UNION

A délkelet-európai aggregátumtervezés ajánlott eljárásainak jövőképe

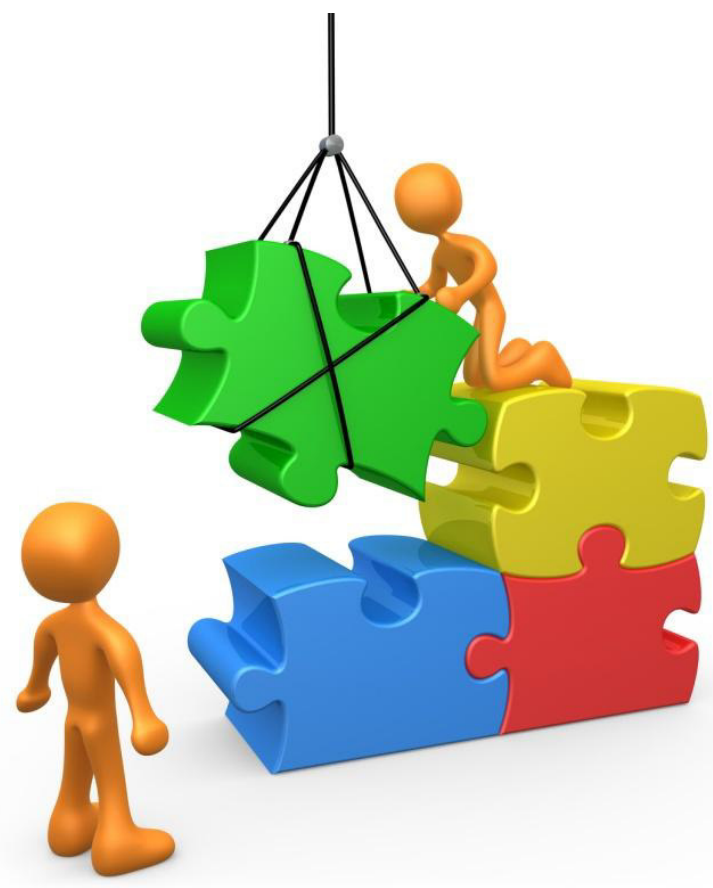

2014 június
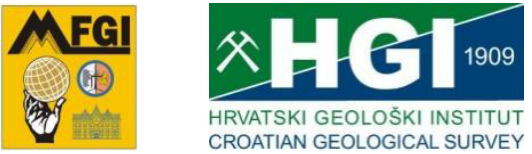



\section{A délkelet-európai aggregátumtervezés ajánlott eljárásainak jövőképe}

\section{Forrás:}

a "Sustainable Aggregates Planning in South East Europe" (SEE/D/0167/2.4/X)

SNAP-SEE projekt 5. Munkacsomagjának jelentései

Honlap: http://www.snapsee.eu

Az 5.3 Tevékenység terméke: az aggregátumtervezést alátámasztó anyagok, amelyek a Multiszektorális elemzésből, az Útmutatóból, és a délkelet-európai (SEE) országok Közös jövőképéből állnak össze.

\section{Közzétételi információk}

Szerkesztés \& megjelenítés: $\quad$ Foteini Stathogianni, Dr. Horváth Zoltán, Sári Katalin

\section{Fedélterv:}

Nyomtatás:

Kiadás éve
Stelios Mavrigiannakis

Magyar Földtani és Geofizikai Intézet

2014

\section{Jognyilatkozat}

Jelen SNAP-SEE kiadvány csak a szerzők véleményét tükrözi, és a Délkelet-Európai Transznacionális Együttmüködési Program Irányító Hatósága nem felelös az itt közölt információk bármilyen további felhasználásáért. CSNAP-SEE project 2014 


\begin{tabular}{|c|c|}
\hline 81 & $\begin{array}{l}\text { Horváth Zoltán, Dr., munkacsomag-vezető, MFGl, Magyarország } \\
\text { Sári Katalin, MFGI, Magyarország } \\
\text { Müller Tamás, MFGI, Magyarország } \\
\text { Plank Zsuzsanna, Dr., MFGl, Magyarország } \\
\text { Ujháziné Kerék Barbara, Dr., MFGl, Magyarország }\end{array}$ \\
\hline 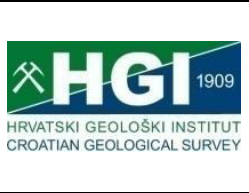 & $\begin{array}{l}\text { Miko, Slodoban, tevékenység-vezetö, HGl, Horvátország } \\
\text { Kruk, Boris, HGI, Horvátország } \\
\text { Dedić, Željko, HGI, Horvátország } \\
\text { Kovačević Galović, Erli, HGI, Horvátország } \\
\text { Hasan, Ozren, HGI, Horvátország }\end{array}$ \\
\hline
\end{tabular}

\section{Lektorok}

\begin{tabular}{|c|c|}
\hline Név & Intézmény \\
\hline Shields, Deborah J., Dr. & Coloradói Állami Egyetem, Amerikai Egyesült Államok \\
\hline O’Brien, Jim & az Európai Aggregátum Szövetség korábbi elnöke, Írország \\
\hline Hámor Tamás, Dr. & Magyar Bányászati és Földtani Hivatal, Magyarország \\
\hline \multicolumn{2}{|l|}{ Köszönetnyilvánítás } \\
\hline
\end{tabular}

\section{Digitális objektum azonosító (DOI)}

10.5474/snapsee-WP5-HU

\section{Hivatkozás}

A jelen kézikönyvre vonatkozó irodalmi hivatkozás formája: Horváth, Z., Miko, S., Sári, K,. Dedić, Ž. (2014): A délkelet-európai aggregátumtervezés ajánlott eljárásainak jövőképe, SNAP-SEE, www.snapsee.eu. doi: 10.5474/snapsee-WP5-HU 


\section{A délkelet-európai aggregátumtervezés ajánlott eljárásainak jövőképe}

TARTALOM

Oldal

Előszó

1

Bevezető információk

1.1 Miért fontos az aggregátumtervezés? 8

1.2 Az aggregátumtervezés sajátos jellemzői 9

$\begin{array}{ll}1.3 \text { A kézikönyv rendeltetése } & 10\end{array}$

1.4 A kézikönyv szerkezete 10

$2 \quad$ Az aggregátumtervezés helyzetének multiszektorális elemzése $\quad 11$

$\begin{array}{lll}2.1 & B e v e z e t e ́ s & 12\end{array}$

2.2 Az aggregátumtervezésre vonatkozó politikák 13

$\begin{array}{lll}2.3 & \text { Aggregátumtervezési politika } & 15\end{array}$

2.3.1 Az aggregátumokra vonatkozó jogi és szabályozási keretek 17

2.3.2 Az aggregátumtervezési fejlesztések jogi korlátai 18

2.4 Összegzés 19

$3 \quad$ Útmutató az aggregátumtervezésnél megfontolandó szempontokhoz 21

$3.1 \quad$ Bevezetés 22

3.2 A tervezési dokumentumok és módszerek tartalma 24

3.2.1 Miért kell az ásványvagyon kitermeléshez hatósági tervezés? 24

3.2.2 Hogyan tervezzék az aggregátumtervezési hatóságok az ásványi nyers- 25 anyag-kitermelést?

3.2.3 Földtan és aggregátumpotenciál 27

3.2.4 Ásványi nyersanyag-/aggregátum nyilvántartás 29

3.2.5 Másodlagos aggregátum-nyilvántartás 29

3.2.6 Aggregátumgazdaság 31

3.2.7 Területfejlesztés és környezetvédelmi hatások 32

3.2.8 Módszertani eljárás- aggregátum védelem/-kitermelés és területren- 33 dezés

3.2.9 Védőtávolságok/átmeneti zónák 35

3.2.10 Elsőbbségi aggregátumzónák elemzése 36

3.2.11 Társadalmi vonatkozások 36 
3.2.12 Helyreállítás és hasznos utófelhasználás 36

$4 \quad$ Az aggregátum tervek optimális tartalmának közös jövőképe 39

4.1 Bevezetés 40

4.2 Jogi-szabályozási keretek $\quad 41$

4.2.1 Országos szint 41

4.2.2 Regionális és helyi szint 43

4.2.3 Uniós vonatkozások 43

4.3 Környezetvédelmi vonatkozások 43

4.3.1 Légszennyezés 44

4.3.2 Zaj 44

$\begin{array}{lll}4.3 .3 & \text { Víz } & 44\end{array}$

4.3.4 Bányászati hulladék 44

4.3.5 Biodiverzitás és ökológiai ellensúlyok 45

4.3.6 Helyreállítás $\quad 45$

4.4 Társadalmi vonatkozások 46

4.5 Gazdasági vonatkozások 46

4.5.1 Határon átnyúló SARM politika 46

$\begin{array}{lll}4.5 .2 & \text { Adózás } & 47\end{array}$

$\begin{array}{lll}4.6 & \text { Szakmai feladatok } & 47\end{array}$

$\begin{array}{lll}4.6 .1 & \text { Nyilvántartás } & 47\end{array}$

$\begin{array}{lll}\text { 4.6.2 } & \text { Földtan és aggregátumpotenciál } & 48\end{array}$

$\begin{array}{lll}4.6 .3 & \text { Ásványvagyon-védelem } & 48\end{array}$

4.7 Technológia 49

4.7.1 Újrafeldolgozás 49

4.7.2 Robbantás 49

$\begin{array}{lll}4.7 .3 & \text { Biztonság } & 49\end{array}$

$4.8 \quad$ Szállítás 50

$5 \quad$ Javaslatok az aggregátumtervezés ajánlott eljárásaihoz 51

$6 \quad$ Hivatkozások $\quad 53$ 


\section{Előszó}

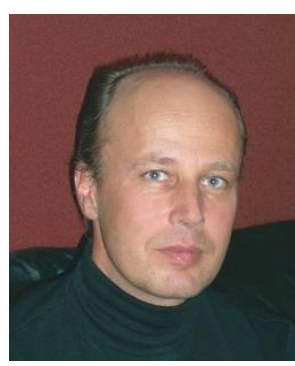

Délkelet-Európa (South East Europe - SEE) gazdag építési aggregátumokban, mint zúzott kő, kavics, homok és egyéb szemcsés inert anyagok, melyeket az építőipar használ fel; azonban ezek a nyersanyaglelóhelyek nem egyenletesen oszlanak el a régióban, ami egyes helyeken bőséget, másutt pedig hiányt eredményez. Ezen túlmenően az egyéb infrastrukturális fejlesztések és környezetvédelmi elvárások miatt egyre nehezebb hozzáférni ezekhez az előfordulásokhoz. Mivel az aggregátumok nagy terjedelmúek és nehezek, szállításuk drága, ezért létfontosságú, hogy a lelőhelyek a piacok közelében helyezkedjenek el. A SEE régióban 2020-ra valószínúleg 50\%-kal több aggregátumkitermelésére lesz szükség annak érdekében, hogy kielégítse a növekvő infrastrukturális igényeket.

A fentiek miatt szükséges áttérni a fenntartható aggregátumkészlet-gazdálkodásra (SARM) és megvalósítani az aggregátumokra vonatkozó fenntartható kínálati mixet (SSM) a régióban, a nyersanyag-hatékonyság növelése és a fenntartható fejlődés támogatása érdekében. A SARM hatékony, alacsony társadalmi-környezeti terheléssel járó külszíni bányászat és hulladékkezelés, ami széleskörű, érdekeltek közti párbeszéddel társul. Egy SSM többféle forrásból származó aggregátumból áll, beleértve az újrafeldolgozott építésibontási hulladékokat, valamint az ipari melléktermékeket (salak), továbbá mind a hazai kitermelésből, mind az importból származó elsődleges nyersanyagokat, amik generációkon át együttesen maximalizálják az aggregátumok nettó hasznát.

A SARM és SSM végrehajtásához szükség van politikai támogatásra és tervezési keretprogramra. A regionális eltérések és történelmi háttér miatt az aggregátumpolitika, tervezés és -gazdálkodás a SEE régió szerte eltérő a különböző politikai szinteken, és csak néhány esetben tekinthető teljesen megvalósultnak. Kihívást jelentenek az aggregátumgazdálkodásra hatással lévő politikák és tervek, valamint a különböző jogi dokumentumokban jelenlévő előírások, melyek megnehezítik a koordinációt és az átfogó értelmezést. Hiányzik továbbá az elsődleges és másodlagos aggregátumtervezés koordinációja. A SEE régióban nem áll rendelkezésre elegendő adat az aggregátumtervezés támogatásához, nincs megfelelő kapacitás és hozzáértés akár az elsődleges, akár a másodlagos aggregátumtervezéshez, és nem megfelelő az érintettek bevonása az aggregátumgazdálkodási tervek elkészítésébe. A SNAP-SEE projekt e hiányosságokkal foglalkozott a SEE régióban, egy élénk, felelősségteljes és fenntartható aggregátum-iparág kialakításának elősegítése érdekében.

A Fenntartható Aggregátumtervezés Délkelet-Európában (SNAP-SEE) projekt konkrét célkitúzése az volt, hogy létrehozzunk és terjesszünk egy Aggregátumtervezési Eszköztárat, ezáltal segítséget nyújtva a SEE régióbeli kormányzatok és érintett felek részére az aggregátumtervezési és -gazdálkodási eljárásaik kifejlesztésében. A SNAP-SEE az ezt megelőző, SEE alap által támogatott, Fenntartható Aggregátumkészlet-gazdálkodás (SARMa) 
projekt (http://www.sarma.eu) eredményeire épült. A SNAP-SEE-t az EU Délkelet-Európai Transznacionális Együttmúködési Programja támogatta (SNAP-SEE, SEE/D/0167/2.4/X), és 12 SEE országból, valamint Törökországból 27 közremúködője volt. A vezető partner a Leobeni Bányászati Egyetem (Ausztria) volt. A SNAP-SEE két évig tartott, 2014 novemberében ért véget.

A SNAP-SEE Aggregátumtervezési Eszköztár 4, egymást kölcsönösen támogató terméket tartalmaz.

1. A délkelet-európai aggregátumtervezés ajánlott eljárásainak jövőképe

Ez a dokumentum a SEE-beli integrált, átfogó, fenntartható tervezésre való áttérés jövőképét mutatja be. Ez tartalmazza a megoldandó kérdések megvitatását, a fenntarthatóbb tervezéshez szükséges közbülső lépéseket, valamint azoknak az összetevőknek az áttekintését, amiket egy fenntartható tervnek tartalmaznia kell.

\section{Egy fenntartható aggregátumterv felépítése}

A módszertani dokumentum egy tervezési ütemtervet mutat be, ami magába foglalja magát a tervezési folyamatot, valamint annak különböző lépéseit. Jól megírt tervezési modulokat nyújt, melyek megtestesítik az „Ajánlott eljárások” jelentésben lefektetett jövőképhez szükséges alapelveket, megközelítéseket és tevékenységeket.

3. Konzultáció az érdekelt felekkel a fenntartható aggregátumtervezés ajánlott eljárásainak alkalmazása során

A „Konzultációs” dokumentum lépésről lépésre útmutatást ad ahhoz, hogy hogyan kell megtervezni és levezényelni az érdekelt felekkel a konzultációkat, ezáltal biztosítva, hogy az ipar, a kormányzat, a kormányzaton kívüli szervezetek és a civil társadalom képviselői hozzá tudnak szólni és részt tudnak venni a tervezési folyamatban. Tartalmaz továbbá kapacitásfejlesztési segédanyagokat is.

4. Adatok és elemzési módszerek az aggregátumtervezéshez: a fenntartható aggregátumtervezés ajánlott eljárásainak támogatása

$\mathrm{Az}$ "Adatok és módszerek” dokumentum a tervezési folyamathoz elengedhetetlen háttérinformációk biztosításához szükséges, a különféle adattípusokat tárgyalja. Adatok definíciói, jelentőségükkel, hozzáférhetőséggel, szerkezettel és szükségletekkel foglalkozik. Ismerteti az adatok hitelesítésének és elemzésének módszereit, beleértve az kereslet-előrejelzésének megközelítéseit is.

Projektkoordinátor

Günter Tiess

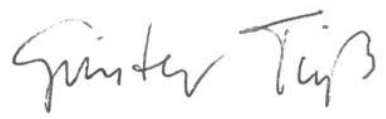

Montanuniversität Leoben

(Leobeni Bányászati Egyetem) 


\section{Bevezető információk}

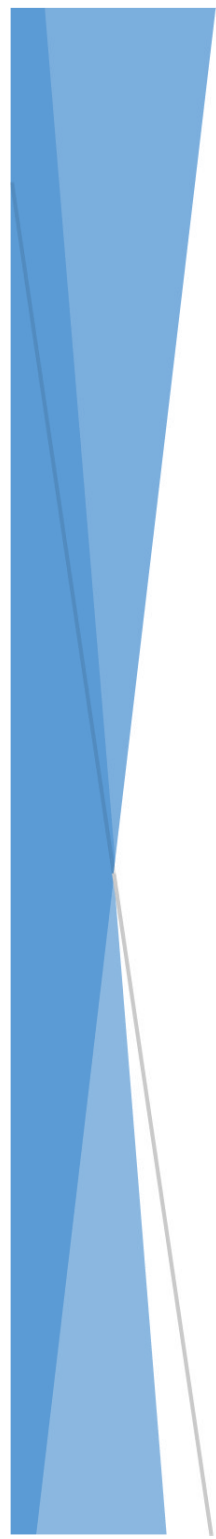

Egy állami vagy regionális szintü, a társadalmi célokat egyértelmüen szolgáló tervezési eljárás összetett és nélkülözhetetlen intézmény. Ehhez az államnak megfelelö információkra van szüksége a tervezési ágazat állapotáról mind az elsődleges, mind a másodlagos aggregátumokra vonatkozóan, valamint a legjobb tervezési módszertan és fenntartható aggregátum/ásványvagyon erőforrás gazdálkodáshoz vezető lépések útmutatójának tekintetében. Egy átfogó, integrált tervezés végrehajtásához meg kell határozni minden, az aggregátumtervezéshez kapcsolódó szöveg helyét és hatáskörét, valamint azt is, hogy hogyan kapcsolódnak egymáshoz az egyes tervezési egységek, és milyen mértékben támogatják az erőforrás hatékonyságot és a fenntarthatóságot.

Az egyes országok tervezési ciklusainak vizsgálata során fontos kérdéskört jelentenek az azonosított tervezési hiányosságok, a tervezési kiválóságok, az ágazatok közti átfedések vagy ellentmondások, valamint az elsődleges és másodlagos aggregátumok iránti igények és preferenciák.

A SEE partnerországok tervezési állapotának, az aggregátumtervezés legjobb útmutatójának, valamint a közeljövőben kialakítandó fö témaköröket tartalmazó közös jövőkép bemutatásával jelen kézikönyv hozzájárul egy átfogóbb, integráltabb, az erőforrásokat hatékonyabban felhasználó aggregátumtervezéshez, országos/regionális szinten. 


\subsection{Miért fontos az aggregátumtervezés?}

Az elsődleges aggregátumok főként a homok, kavics és zúzott kő; a másodlagos aggregátumok építési és bontási hulladékok, ipari aggregátumok újrafeldolgozásából, építési munkálatokból, stb. származnak (SARMa Szótár). A gazdasági növekedésre vonatkozó UEPG adatok alapján (Tiess 2010) a jövőben több aggregátumra lesz szükség Délkelet-Európában. Az aggregátumok kiemelten fontosak a gazdasági növekedéshez. Bár az aggregátumvagyon korlátlannak tűnik (a legtöbb előfordulás ismert), az ehhez való hozzáférés egyre nehezebbé válik. Nemcsak a védett területek (pl.: biológiai sokféleség védelme és kulturális örökségvédelem) és társadalmi hozzáállás miatt, hanem az épület- és úthálózat-fejlesztések is gátolják az aggregátumkészletekhez való hozzáférést a kitermelési szempontból potenciális területek kisajátításával és nem bányászati célú hasznosításával. Az aggregátumellátás tervezése tehát elsődleges fontosságú.

Bár társadalom aggregátumigényét a magán aggregátumszektor elégíti ki, az állam felelős azért, hogy ennek alapjai az aggregátumtervezési folyamaton keresztül biztosítva legyenek. Ez olyan közpolitikákat jelent, amelynek célja a biztonságos aggregátumellátás biztosítása az országban vagy a régióban zajló építkezésekhez, az épületektől az infrastruktúráig. Az államnak kell, vagy kellene összegyűjtenie az öszszes, az országban található elsődleges és másodlagos aggregátumvagyonra vonatkozó információt, és kezelni ezeket a nyilvántartásokat. A fejlesztések jogi hátterének megteremtése és a jövőbeli irányok meghatározása szintén állami kompetencia alá esik. Így az összes információ felhasználásával csak az állam tud létrehozni egy átfogó aggregátumtervezést, amelyet országos, regionális és helyi szinten harmonizálni kell.

A tervezési rendszernek alapvető szerepe van abban, hogy keretet biztosít az ásványvagyon-hasznosítási javaslatokra vonatkozó, helyes és következetes döntések meghozásához. Az ásványi nyersanyag-gazdálkodási tervek, főképp, habeépülnek a területrendezési tervekbe, segítik az ipar és az illetékes hatóságok képviselőit egy hosszú távú, stabil, az ásványvagyon kitermelési tervezési keret létrehozásában. Emellett hatékonyan segítik elő az integráltabb fenntartható fejlődési stratégia kialakítását, amely már a döntéshozói folyamat nagyon korai szakaszában figyelembe veszi a szélesebb társadalmi szempontokat, mint pl. természetvédelmet is. Így a hatóságoknak át kell kutatniuk a saját fejlesztési tervpolitikájukat és döntéseiket, hogy figyelembe vegyék az összes, ásványi nyersanyagokhoz kapcsolódó költséget és hasznot, tekintettel a fenntartható fejlődés alapelveire. Az ásványi nyersanyag-gazdálokdás tervezéséhez kapcsolódó fő célok a következők:

Társadalmi fejlődés, amely mindenki szükségletét felismeri: egy megfelelő, a társadalom mai és jövőbeli igényeit kielégítő ásványi nyersanyagellátáson 
keresztül biztosítani a növekvő jólét hasznát a kényelem megóvásával és növelésével

$\checkmark$ Hatékony környezetvédelem: védeni a saját belső értékkel rendelkező értékeket, mint pl. a vadvilág, a tájak és a kulturális örökség, valamint védeni az emberi egészséget és biztonságot az ásványvagyon-kitermelés és -szállítás okozta környezeti károk elfogadható határérték alatt tartásával; végül kompromisszum nélkül biztosítani a helyreállítást és utókezelést egy megfelelő és haszonnal járó utóhasznosítás céljára;

$\checkmark$ A természeti erőforrások körültekintő használata: hatékony felhasználással, újrafeldolgozással és a hulladéktermelés minimalizálásával elősegíteni a nem megújuló erőforrások megóvását a következő generációk számára; megóvni a megújuló erőforrásokat a komolyabb sérülésektől vagy szennyeződéstől; valamint támogatni a megfelelő alternatív agyagok használatát; végezetül

$\checkmark$ Magas szintű és stabil gazdasági fejlődés fenntartása: megfelelő ásványi nyersanyagellátás biztosítása ésszerű árakon; az ásványvagyon megóvása a következő generációk számára.

\subsection{Az aggregátumtervezés sajátos jellemzői}

Az ásványi nyersanyagellátás tervezésének számos olyan sajátossága van, amely nem jellemző fejlesztésekre (http://planningguidance.planningportal.gov.uk):

$\checkmark \quad$ az ásványi nyersanyag csak ott vonható múvelés alá (pl. termelhető ki), ahol természetes módon előfordul, tehát a gazdaságos és környezetvédelmi szempontból megfelelő ásványi nyersanyag-kitermelés térbeli elhelyezésének lehetőségei korlátozottak. Ez azt jelenti, hogy ásványvagyont védeni szükséges az olyan, nem ásványvagyon célú fejlesztésekkel szemben, amelyek befolyásolják az ásványvagyon terveket, illetve mérlegelni kell a nem ásványvagyon célú fejlesztések jóváhagyását a kijelölt védett ásványvagyon területeken;

$\checkmark \quad$ a munkálatok csak ideiglenes földhasználatot jelentenek akkor is, ha hosszú időt vesznek igénybe;

$\checkmark$ a munkálatoknak lehetnek kedvező és kedvezőtlen környezeti hatásai is, viszont néhány kedvezőtlen hatás hatékonyan mérsékelhető;

$\checkmark$ mivel az ásványi nyersanyag-kitermelés folyamatos fejlesztési múvelet, rendszeres monitoring tevékenységet kell végezni, és szükség esetén szankciókkal kell biztosítani a bányászati műveletek hatásainak mérséklését; végezetül

$\checkmark$ utómunkálatok: a területet helyre kell állítani, hogy alkalmas legyen hasznot hozó utóhasználatra. 


\subsection{A kézikönyv rendeltetése}

Az aggregátumtervezési politikák aggregátumokra vonatkozó, nyílt kormányzati célkitǔzések; a tervezés egy hivatalos eljárásrend létrehozása, amelyet a célok eléréshez követni kell; a gazdálkodás pedig a tervek kezelése és végrehajtása. A SNAP-SEE Fenntartható Aggregátumtervezés Délkelet-Európában (SEE) az alábbi kulcskérdéssel foglalkozott: hogyan tudják a SEE országok és régiók fejleszteni az aggregátumtervezési politikájukat, az erőforrás-hatékonyság növelése érdekében integráltan tervezni az elsődleges és másodlagos aggregátumokat, illetve növelni az érdekelt felek (pl. illetékes hatóságok, ipari és civil társadalom) közti kapacitás szintjét az aggregátumgazdálkodás, -tervezés és -ellátás figyelembe vételével.

Emiatt a tervezés állapota, a tervezéshez ajánlott eljárások (útmutató) és a szükséges fő témakörök, azaz a közös jövőkép alapvető összetevők a politikák és a jogiszabályozási háttér fejlesztésénél, illetve ezen keresztül a fenntartható aggregátumtervezésnél.

\subsection{A kézikönyv szerkezete}

A Kézikönyv felépítése a következő: a 2 . fejezet bemutatja a tervezés állapotának multiszektorális elemzését, elsőként taglalva az összes kapcsolódó politikát, majd az aggregátumtervezést, annak szabályozási kereteit és jogi korlátait.

A 3. fejezet egy útmutató a jobb tervezés kialakításához. Ez a fejezet általános információt nyújt az ásványvagyon-tervezésről és annak dokumentumairól (tudásbázis, aggregátumkereslet, aggregátumkínálati potenciál, hatások, életciklus-elemzés), valamint ismerteti a tervezési dokumentumok és módszerek tartalmát (engedélyezési hatóságok, aggregátumpotenciál, nyilvántartás, aggregátumgazdaság, területrendezés, társadalmi szempontok, helyreállítás, stb.).

A 4. fejezet az aggregátumtervezésre vonatkozó délkelet-európai közös jövőképet tartalmazza. Bemutat egy ideális, jövőbeli, jogi-szabályozási keretrendszert országos/regionális és uniós szinten. Ezután tárgyalja a kapcsolódó környezetvédelmi (légszennyezés, zaj, víz, bányászati hulladék, biológiai sokféleség és helyreállítás), társadalmi-gazdasági vonatkozásokat (határon átnyúló SARM politika, adózás) és a szakmai feladatokat (nyilvántartás, aggregátumpotenciál, ásványvagyon-védelem). Végül bemutatásra kerül a technológia (újrafeldolgozás, robbantás, biztonság) és a szállítás.

Az 5. fejezet összefoglalja az aggregátumtervezésre vonatkozó legfontosabb ajánlásokat. 


\section{Az aggregátumtervezés helyzetének multiszektorális elemzése}

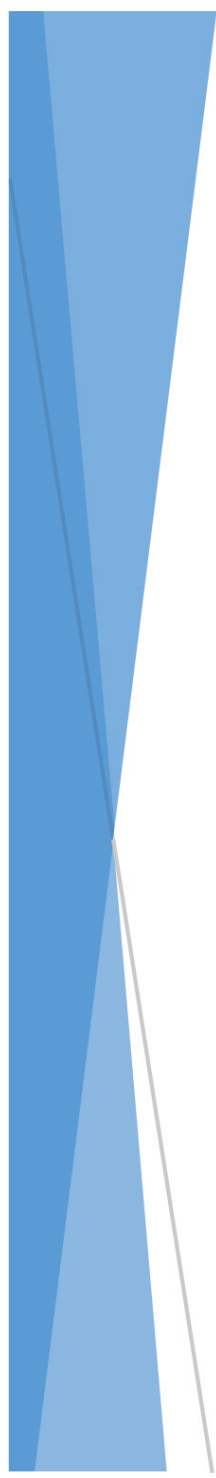

A multiszektorális elemzés célja annak meghatározása, hogy hogyan történik a tervezés a partnerországokban, beleértve azt is, hogy az egyes partnerországok hol tartanak a tervezési ciklusban. Az aggregátumellátás tervezése kormányzati tevékenység, amelynek célja olyan politikák, jogi keret, tevékenységek és információk kialakítása, amely az országos/regionális gazdaságok számára biztosítja a megfelelő mennyiségü, elsődleges és másodlagos aggregátumok elérhetőségét, rövid, közép és hosszá távon. A tervezéshez szükséges a várható kereslet, ellátási források és korlátok, ezzel együtt az aktuális politikák, jogi és szabályozási keretek, valamint ezek hatékonyságának és sok egyéb változónak a figyelembe vétele. 


\subsection{Bevezetés}

Az aggregátumvagyon-gazdálkodás multiszektorális elemzése a különböző hatóságoknál előforduló tervezési gyakorlat összetettsége miatt szükséges. Ez módszer feltárja, hogy hol és hogyan kerülnek említésre az aggregátumok az aggregátumellátásra hatással levő, különböző szektorokat képviselő jogi dokumentumokban.

Az aggregátummal kapcsolatos szektorok az alábbiak:

$\checkmark$ bányászat/ásványvagyon-gazdálkodás

$\checkmark$ környezetvédelem, beleértve a vízgazdálkodást és a természetvédelmet

$\checkmark$ zöld közbeszerzés

$\checkmark$ hulladékgazdálkodás

$\checkmark$ újrafeldolgozás

$\checkmark$ területrendezés

A 2.1 ábra bemutatja az aggregátumtervezési politikákhoz kapcsolódó szektorokat.

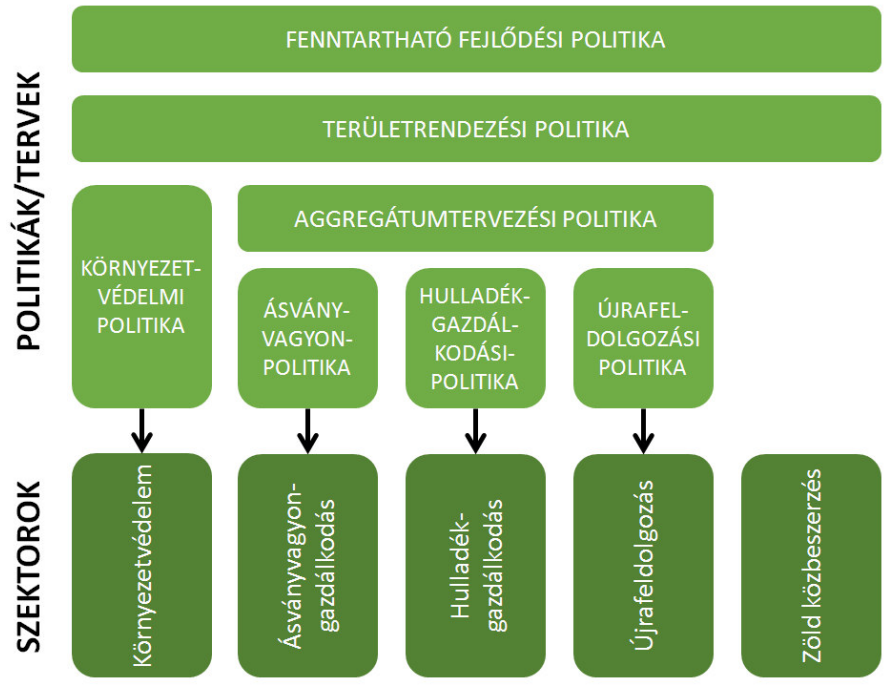

2.1. ábra: Az aggregátumtervezési politikákhoz kapcsolódó szektorok

Ezekhez a szektorokhoz politikák és szabályozások tartoznak, mint pl. fenntartható fejlődési politika, ásványvagyon-politika, területrendezési politika, hulladékkezelési politika, újrafeldolgozási politika (ami gyakran része vagy a hulladék, vagy az ásványvagyon politikának) és környezetvédelmi politika. A területrendezési politika és a 
fenntartható fejlődési politika több szektort is lefed. A fenntartható aggregátumtervezési politikáknak együttesen kell figyelembe venniük az elsődleges és másodlagos (az utóbbi hulladékokból, vég- és melléktermékekből származó) aggregátumokat.

\subsection{Az aggregátumtervezésre vonatkozó politikák}

A 2.2 ábrán lévő multiszektorális elemzés bemutatja az aggregátumtervezés állapotát Albániában (AL), Ausztriában (AT), a Hercegboszniai kantonban (BoszniaHercegovina, BA), Horvátországban (HR), Görögországban (GR), Magyarországon (HU), Olaszország Emilia-Romagna régiójában (IT-ER) és Trento autonóm tartományában (IT-T), Montenegróban (ME), Romániában (RO), Szerbiában (RS), Szlovákiában (SK), Szlovéniában (SI) és Törökországban (TR). A SEE országok/régiók nagy része rendelkezik fenntartható fejlődési, ásványvagyon, területrendezési, hulladékgazdálkodási és környezetvédelmi politikákkal. Azonban közülük csak néhány veszi figyelembe az aggregátumpolitikát és az újrafeldolgozást.

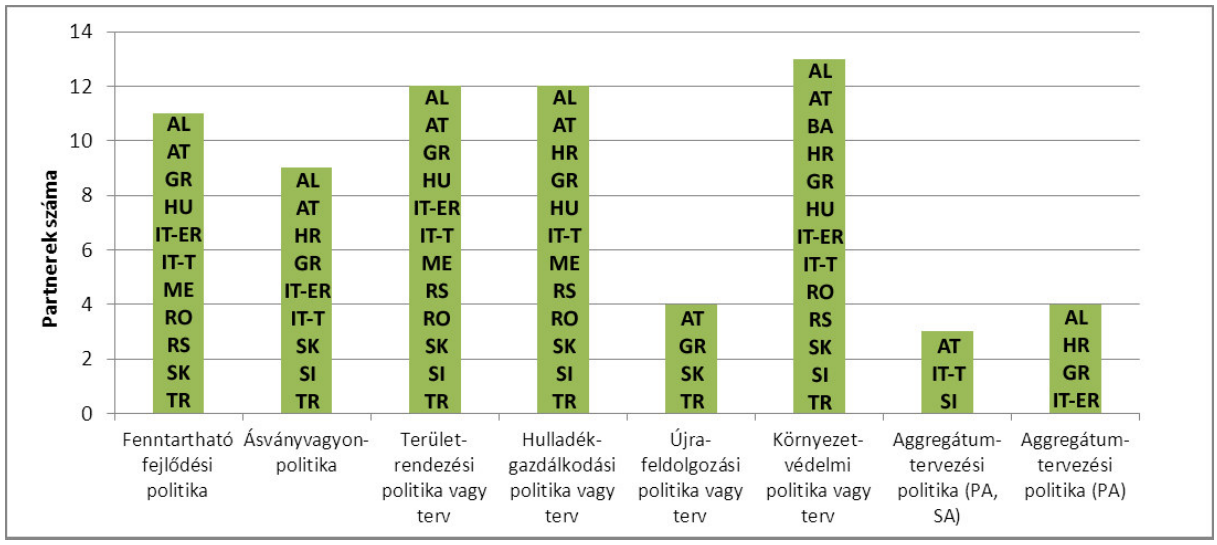

2.2. ábra: Fenntartható fejlődési politika, ásványvagyon politika, területrendezési politika, hulladékgazdálkodási politika, újrafeldolgozási politika, környezetvédelmi politika és aggregátumtervezési politika illusztrálása a SEE országokban. PA: elsődleges aggregátum; SA: másodlagos aggregátum

Tizenegy ország vagy régió rendelkezik fenntartható fejlődési politikával. Ebből hét foglalkozik az ásványi nyersanyaggal, de többnyire csak olyan, általános célok kitűzésén keresztül, mint az ésszerű ásványvagyon-gazdálkodás és erőforrás-hatékonyság. öt partner foglalkozik az aggregátumokkal és nyolc ország vagy régió fenntartható fejlődési politikájában található meg az újrafeldolgozás, míg csak négy partner veszi figyelembe a zöld közbeszerezést. Több partner fenntartható fejlődési politikája emlí- 
ti az ésszerű és fenntartható ásványvagyon-gazdálkodást minden típusú ásványi nyersanyagra vonatkozóan, de csak általánosságban.

Kilenc ország vagy régió rendelkezik ásványvagyon-politikai keretrendszerrel, mindegyikük foglalkozik aggregátumokkal az ásványvagyon-politikájukban (2.3 ábra). Nyolc partnerország/régió foglalkozik területrendezéssel. Görögország, Szlovákia és Szlovénia figyelembe veszi újrafeldolgozást; Albánia, Görögország és Szlovákia a hulladékgazdálkodást.

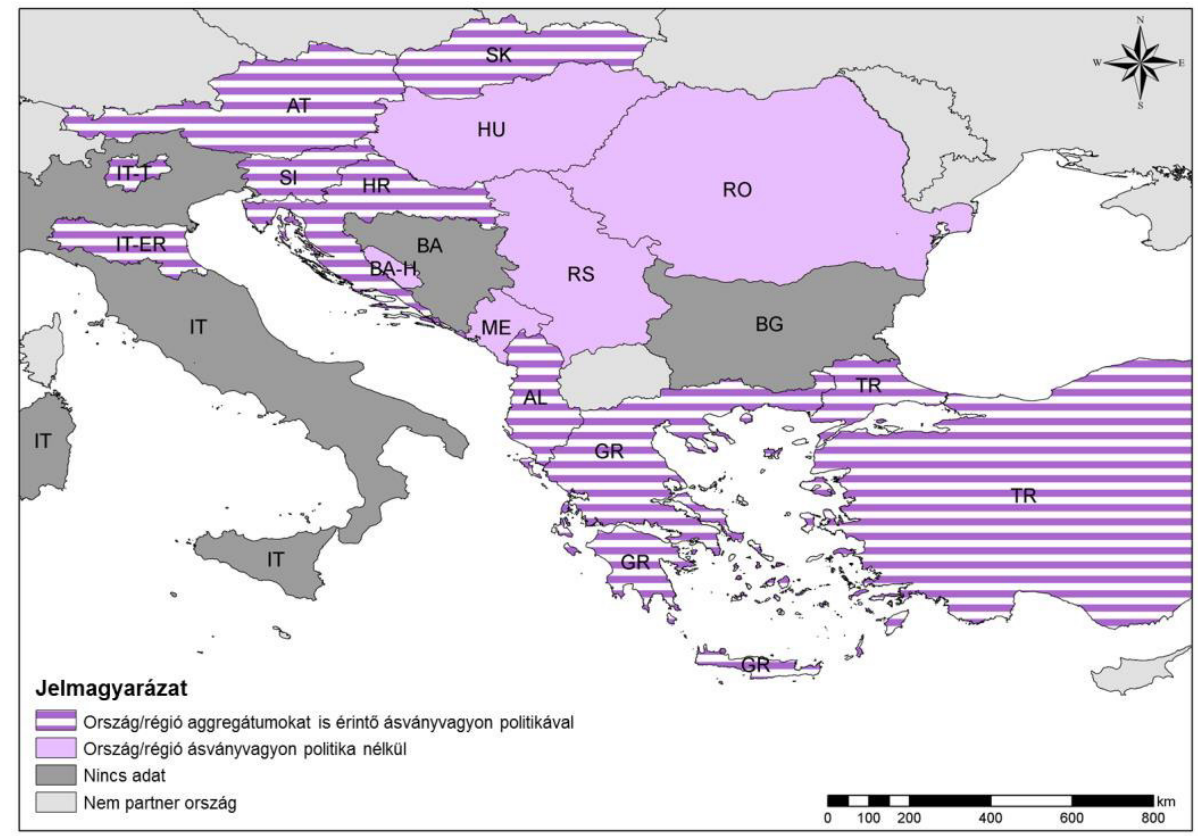

2.3. ábra: Ásványvagyon-politika Délkelet-Európában

12 országnak vagy régiónak van területrendezési politikája. Ebből tízben foglalkoznak az ásványi nyersanyag hozzáférhetőségének biztosításával, védelmével és fenntartható használatával. Közülük 8 foglalkozik kifejezetten az aggregátumokkal. 4 ország említi az újrahasznosítást a területrendezési politikájában. Csak Ausztria foglalkozik zöld közbeszerzéssel.

A Hercegboszniai kanton és az olasz Emilia-Romagna régió kivételével minden partnernek van hulladékgazdálkodási politikája, bár Emilia-Romagna régió hulladékgazdálkodási politikája kialakítás alatt áll. Ezek közül 10 foglalkozik újrahasznosítással. 7 
ország vagy régió veszi figyelembe az ásványi nyersanyagokat, és 5 partner foglalkozik kifejezetten aggregátumokkal. A magyar és montenegrói hulladékgazdálkodási politika azonban nem foglalkozik minden aggregátummal, csak a C\&D hulladékkal. 4 partner említi meg a zöld közbeszerzést a hulladékgazdálkodási politikájában. Csak Görögország foglalkozik a zéró hulladékkal. 10 ország vagy régió vezette be az Európai Bizottság jogalkotását, így az ő hulladékgazdálkodási politikájuk tartalmaz újrahasznosítási ösztönzési tervet. Csak 4 ország rendelkezik a hulladékgazdálkodási politikától elkülönült újrahasznosítási politikával.

Montenegrót kivéve minden partnernek van környezetvédelmi politikája. 7 országnál megjelenik az ásványvagyon és az újrahasznosítás a környezetvédelmi politikában, bár a magyar és a szerb környezetvédelmi politikában az újrafeldolgozást az aggregátumoktól függetlenül szerepel. Ausztriában, Magyarországon és Emilia-Romagna régióban megemlítik a zöld közbeszerzést.

A potenciális másodlagos nyersanyagok (pl. bányászati hulladék, C\&D hulladék, erőmúvi, kohászati, hulladékégetőkből származó hamu és salak) kezelése nem egységes a SEE régióban. Szlovéniában az újrafeldolgozást törvény írja elő. Magyarországon támogatják az újrahasznosítást, de az nem mindig kötelező. Szabályozva van a szelektív gyűjtés és lerakás. Montenegróban nincs törvénybe iktatva az újrahasznosítás, de a bányászati hulladékok kezelése hozzátartozik a bányászati tevékenységhez. Szerbiában szinte minden másodlagos nyersanyagtípus lerakóba kerül. A gyakorlatban a másodlagos nyersanyagokat ártalmatlanítják (Szerbia), külön gyújtik és újrahasznosítják (Trento autonóm tartomány (IT), Ausztria, Szlovénia), vagy ezek kombinációjaként kezelik (Magyarország, Horvátország, Montenegró, Albánia).

\subsection{Aggregátumtervezési politika}

Csak 3 partnernek (Ausztria, Szlovénia, Trento autonóm tartomány (IT)) van mind elsődleges, mind másodlagos aggregátumokkal foglalkozó aggregátumtervezési politikája. 4 további országban vagy régióban (Albánia, Horvátország, Görögország és Emilia-Romagna régió(IT)) az aggregátumpolitika csak az elsődleges aggregátumokkal foglalkozik (2.4 ábra).

Az aggregátumtervezésért felelős intézmények elsősorban bányászati, területrendezési és egyéb, pl. gazdasági, fenntarthatósági, vízgazdálkodási hatóságok, és regionális vagy helyi önkormányzatok. Minden országban, ahol létezik aggregátumtervezés, ez az érintettek (önkormányzatok, állami és magán intézmények) bevonásával jött létre. Ezeket az aggregátumpolitikákat/terveket a szükségletektől és a dokumentum 
típustól függően rendszeresen (a Trento autonóm tartományban (IT) 10 évenként, Horvátországban 10-12 évenként) felülvizsgálják.

Néhány országban (Ausztria, Horvátország, Szlovénia és Trento autonóm tartomány) foglalkoznak a kereslet-kínálati egyensúllyal; a jövőbeli keresletet főképp a jelenlegi aggregátumtermelés és a jövőbeli területfejlesztési tervek alapján becsülik meg.

Az aggregátumkitermelés és más (potenciálisan érintett) felhasználási célok értékeléséhez főként térinformatikai adatokat használtak. Például domborzati, infrastrukturális, kőfejtők helyszíneire vonatkozó, hidrogeológiai, környezetvédelmi kockázati adatok, valamint védett területek (természeti és kulturális örökség) elérhetők GIS formátumban. Trento autonóm tartományban (IT), Horvátországban és néhány osztrák régióban használnak továbbá statisztikai adatokat is (pl. termelés, fogyasztás, típus, újrahasznosítás).

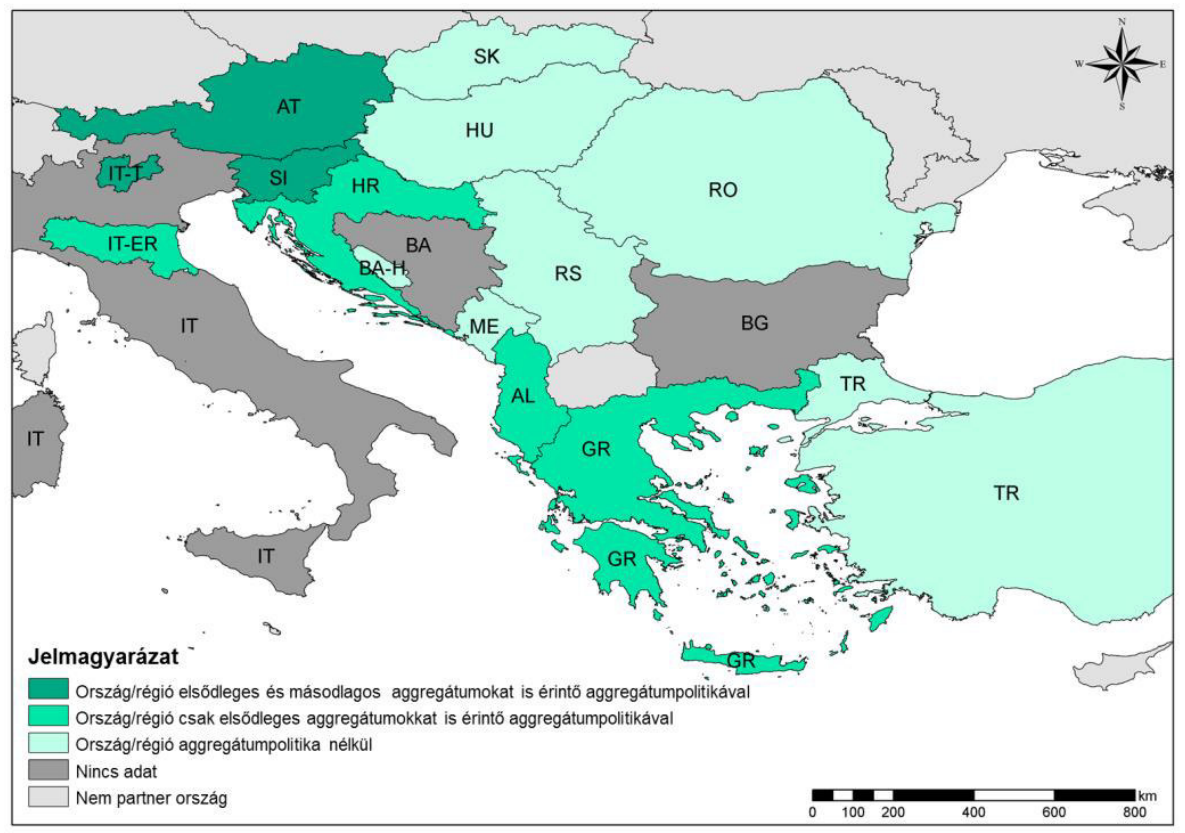

2.4. ábra: Aggregátumtervezési politikák Délkelet-Európában

A területrendezés kereteibe ágyazott aggregátumtervek számos egyéb témával is foglalkoznak, pl. természetvédelem, társadalmi hatások, gazdasági részesedés, szállítás, utókezelés stb. Trento autonóm tartományban és Emilia-Romagna régióban (IT) a környezetvédelem kiemelten fontos. Szlovéniában számos további témakört érint az 
aggregátumterv, (pl. vadászat, méhészet, oktatás). Az aggregátumtervezési politikák egyéb törvényekhez kapcsolódnak, mint pl. területrendezési, hulladékkezelési és környezetvédelmi politikákhoz, szállítási szabályozásokhoz.

\subsubsection{Az aggregátumokra vonatkozó jogi és szabályozási keretek}

Összhangban a SARMA projekt jogi jelentésével (Hámor 2011), az aggregátumkitermelési jog tulajdonosa általában az állam; Ausztriában, Görögországban, Szlovákiában és Emilia-Romagna régióban azonban a földtulajdonos, mint, míg Trento autonóm tartományban mindkettő (2.5 ábra).

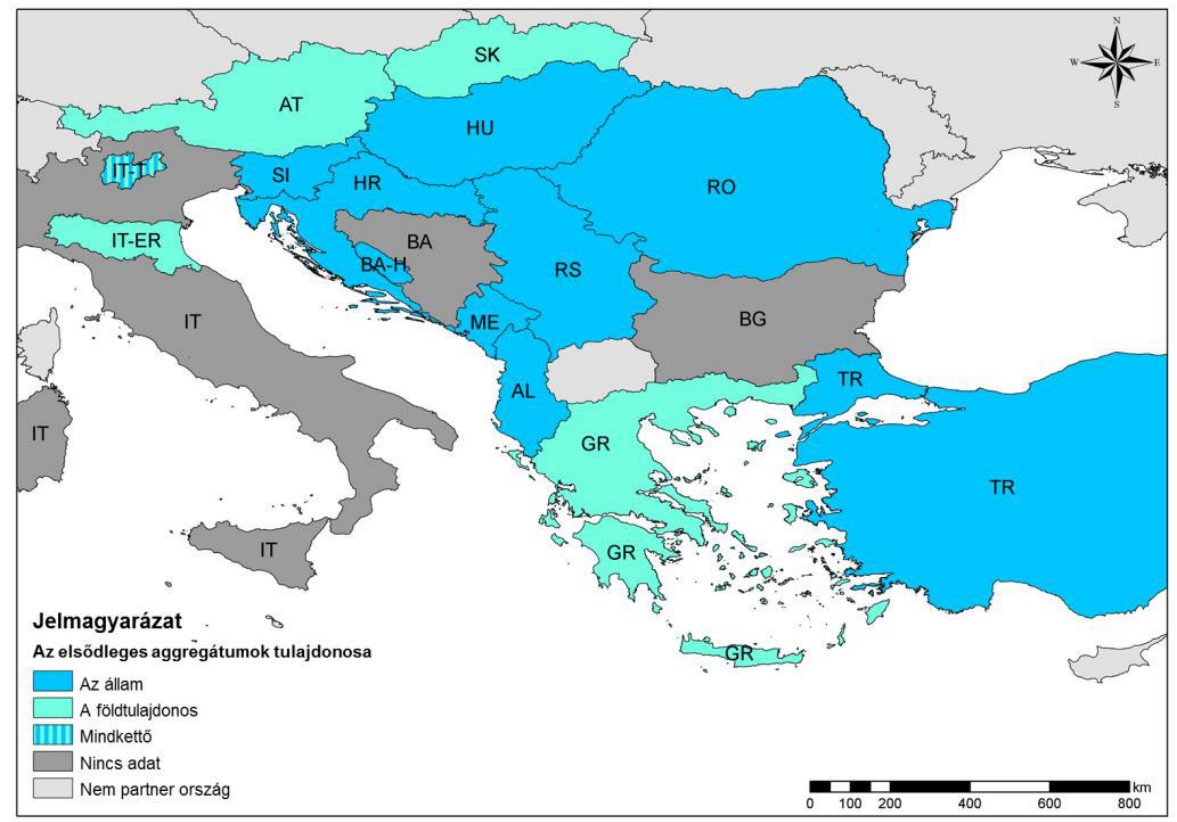

2.5. ábra: Az elsődleges aggregátumok tulajdonszerkezete Délkelet-Európában

A bányászati (és földtani) hatóság fontos szerepet játszik az aggregátumtervezéshez kapcsolódó engedélyezési folyamatban. Számos országban a környezetvédelmi hatóság, a helyi önkormányzat, a területrendezési és egyéb hatóságok szintén felelősek az engedélyezésért.

Az aggregátum vonatkozású természetvédelmi kérdésekkel minden partnerországban a környezetvédelmi engedélyezésbe beépülve foglalkoznak. Románia és Törökor- 
szág kivételével e szabályozás átvétele az aggregátumkitermelés számára tiltott területek kijelöléséhez vezet.

Az engedélyezési fázis során minden partnerország biztosítja a társadalmi vészvételt: Albániában közmeghallgatások útján, Olaszországban és Törökországban írásos formában, míg a többi SEE országban mindkét módon. Az engedélyezési eljárás nem egységes a SEE országokban. Legtöbbször egyablakos formában történik, de párhuzamos vagy kevert, azaz részben egyablakos, részben párhuzamos, modelleket is alkalmaznak (2.6 ábra).

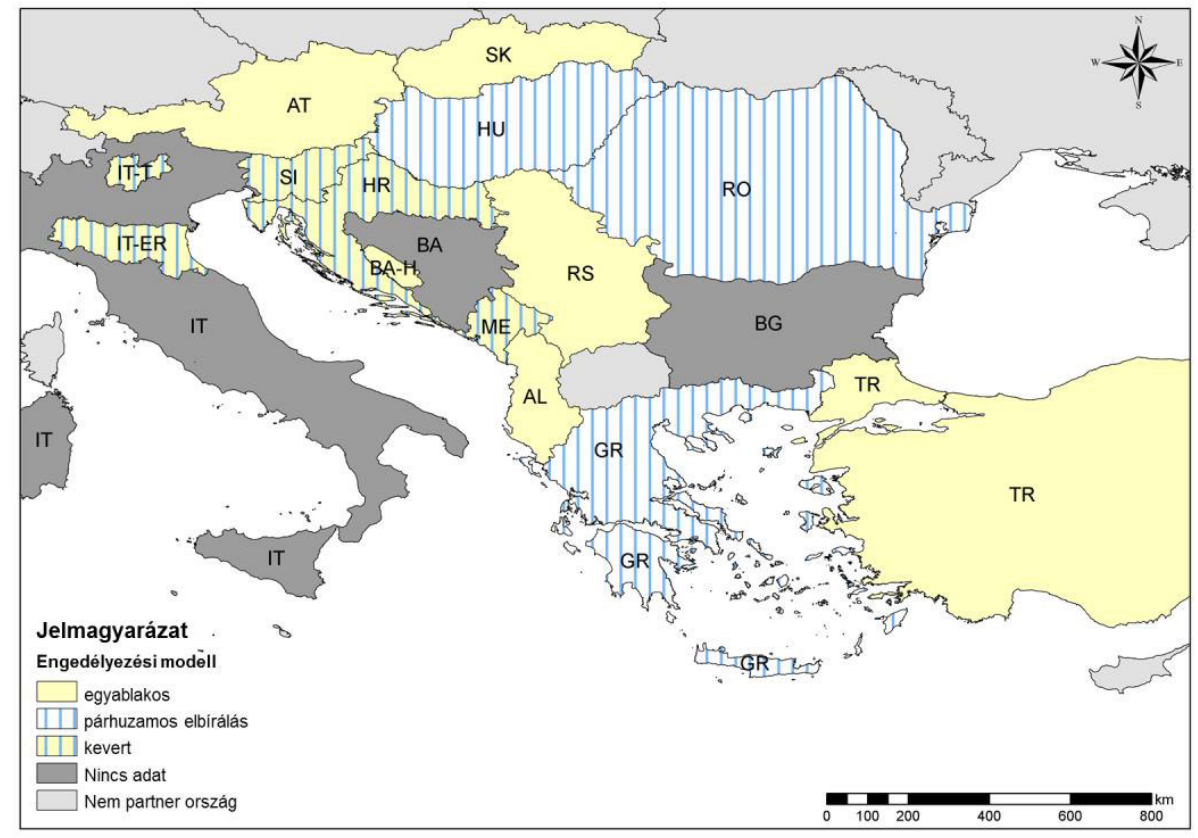

2.6. ábra: Engedélyezési modellek Délkelet-Európában

\subsubsection{Az aggregátumtervezési fejlesztések jogi korlátai}

A SEE országokban különböző jogi és szabályozási korlátozások akadályozzák az aggregátumtervezés fejlődését. Az uniós projektek (pl.: SARMa szótár) javaslataival harmonizáló, egységes terminológia hiánya problémát okoz Magyarországon és Romániában. Trento autonóm tartományban a nyersanyag (természetes, hulladék vagy termék) jogi definíciója nagyban eltér a termelési folyamat során; emiatt ugyanahhoz a nyersanyaghoz a jogi meghatározástól függően különböző eljárástípusok tartoznak. Így a kőfejtőből kitermelt aggregátum jogi szempontból eltér az építési munkálatok- 
ból származó aggregátumtól annak ellenére, hogy földtani szempontból mindkét aggregátum azonos. Az eltérő jogi meghatározások jelentősen különböző bürokratikus eljárásokhoz vezet, annak ellenére, hogy az aggregátumok ásványtani és műszaki jellemzői azonosak.

A talajvízszint alatti rétegekből történő aggregátum kitermelés érzékeny téma Ausztriában; Horvátországban csak az aktív külfejtéseket veszik figyelembe a területrendezési tervekben, és jelölik ki bányászati területekként; Montenegróban eltérnek a helyi önkormányzatok területrendezési tervei az országos területrendezési tervtől. A Natura 2000 területek részben korlátozzák a bányászati tevékenységet számos SEE országban, mint pl. Ausztriában, Magyarországon és Szlovéniában. Emilia-Romagna régióban a fő problémát a hosszú várakozási időt igénylő, erősen hierarchikus tervezési és engedélyezési rendszer jelenti. A Hercegboszniai kantonban és Szerbiában hiányoznak az aggregátumtervezésre vonatkozó szabályozások. A földterület tulajdonjoga problémákat okoz Albániában és Szlovákiában. Szlovéniában problémát okoz az érintett és felelős intézmények közötti koordináció hiánya, valamint a felszíni és tenger alatti kutatások forráshiánya.

\section{4 Összegzés}

Aggregátumtervezési politikai keretrendszer (területrendezésen alapuló) Ausztriában, Trento autonóm tartományban és Szlovéniában létezik. A többi partnerországban az aggregátumtervezési politikához kapcsolódó legfontosabb dokumentumok a bányászati törvény vagy terv, koncessziós törvény, környezetvédelmi törvény, fenntartható fejlődési stratégia, hulladékkezelési törvény vagy stratégia és területrendezési törvény. Trento autonóm tartomány, Ausztria, Szlovénia és Albánia rendelkezik ásványvagyon-gazdálkodási tervekkel (ásványvagyonterv, bányászati stratégia), míg a többi SEE országban a bányatörvény (Magyarország, Hercegboszniai Kanton, Horvátország, Montenegró) illetve a koncessziós törvény (Hercegboszniai Kanton, Montenegró) foglalkozik az aggregátumokkal.

A legtöbb SEE országban az elsődleges és másodlagos aggregátumokat elkülönülten kezelik, pl. eltérő a felelős hatóság; vagy az aggregátumgazdálkodás még el sem kezdődött (Hercegboszniai Kanton, Montenegró, Magyarország, Románia, Szerbia, Szlovákia és Törökország). A másodlagos aggregátumokkal legtöbbször az adott ország vagy régió hulladékkezelési politikája foglalkozik. A hulladékgazdálkodás folyamatban van (eltérő szinteken) és elkülönül az erőforrás gazdálkodástól. Nem minden másodlagos aggregátumtípus jelenik meg a jogszabályokban: főképp az építési és bontási, valamint a bányászati hulladékra vonatkoznak a szabályozási keretek. 
A SARM (fenntartható aggregátumkészlet-gazdálkodás) és SSM (Fenntartható kínálati mix) támogatása eltérő: néhány országban legalább elméletben elfogadják (Szlovénia, Horvátország, Szerbia és Montenegró), míg más országokban nem ismertek és nem elfogadottak (Magyarország, Hercegboszniai Kanton).

\section{A bányatelkek és természetvédelmi területek közti potenciális konfliktusokat nem} kezelik megfelelően minden partnerországban. Ez azt eredményezi, hogy majdnem minden partnerországban (Románia és Törökország kivételével) az ilyen területeken teljes tilalom alá esik az aggregátumkitermelés, holott a Nem energetikai célú kitermelö tevékenység a Natura 2000 elöírásainak megfelelően című útmutató dokumentum szerint „A NEEI (nem energetikai célú kitermelő iparág) tevékenysége nincs automatikusan kizárva a Natura 2000 hálózat körül és azon belül. Ehelyett a bányászati tevékenységeknek követniük kell az Élőhelyvédelmi Irányelv 6. cikkének kikötéseit annak érdekében, hogy ezek a tevékenységek ne befolyásolják hátrányosan a Natura 2000 területeket." (EC 2010a, 7. o.). A tiltott minősítést kapott területek komoly problémát jelentek sok SEE országban, ami a legfontosabb érdekelt felek (pl. döntéshozók, környezetvédelmi hatóságok, bányavállalkozók) közti konzultációval megoldható vagy enyhíthető lenne.

Számos partnerországban a területrendezési politikai keretrendszer fontos információkat tartalmaz az aggregátumtervezéshez, pl. természet- vagy kulturális örökségvédelmi területek - habár a kijelölt bányászati területeken nincs aggregátumokra vonatkozó információ. 


\section{3. Útmutató az aggregátumtervezésnél megfontolandó szempontokhoz}

A cél annak meghatározása, hogy hogyan lehet javítani a tervezést az egyes országokban. A partnerországok képviselői felkérést kaptak egy útmutató dokumentum létrehozására, amely tükrözi az egyes országok helyzetét és az érdekeltségi hálózatát. Meg kellett határozniuk továbbá azokat a tervezési szempontokat, melyek alkalmazhatók és relevánsak minden SEE országban, mert ezek az információk a Közös Jövőképbe és az Aggregátumtervezési Rendszerbe beépítve növelhetik a kohéziót és a harmonizációt. 


\subsection{Bevezetés}

Az ásványvagyon-tervezési politika része az országos ásványvagyon-gazdálkodási politikai keretrendszernek (Tiess 2011a; EC 2010b). A országos aggregátumpolitika azon állami múveletek összességeként határozható meg, amelyek befolyásolják az ásványvagyon iránti keresletet és kínálatot az ország területén (Tiess 2011a). Ebbe bele tartozik az aggregátum-előfordulások területrendezéssel megvalósított védelme (azaz a nyersanyagok védelme). E keretrendszerrel összefüggésben, országos szinten ki kell fejleszteni egy aggregátumtervezési politikát azon stratégiai kérdések figyelembe vételével, amelyekkel kapcsolódik a regionális/helyi (operatív) tervezési szinthez. Fontos továbbá a hierarchikus tervezési alapelv: a tervezési folyamat 1:100 000-ről indul (például) és részletes skáláig fejlődik (regionális: 1:25 000, helyi: 1:5 000).

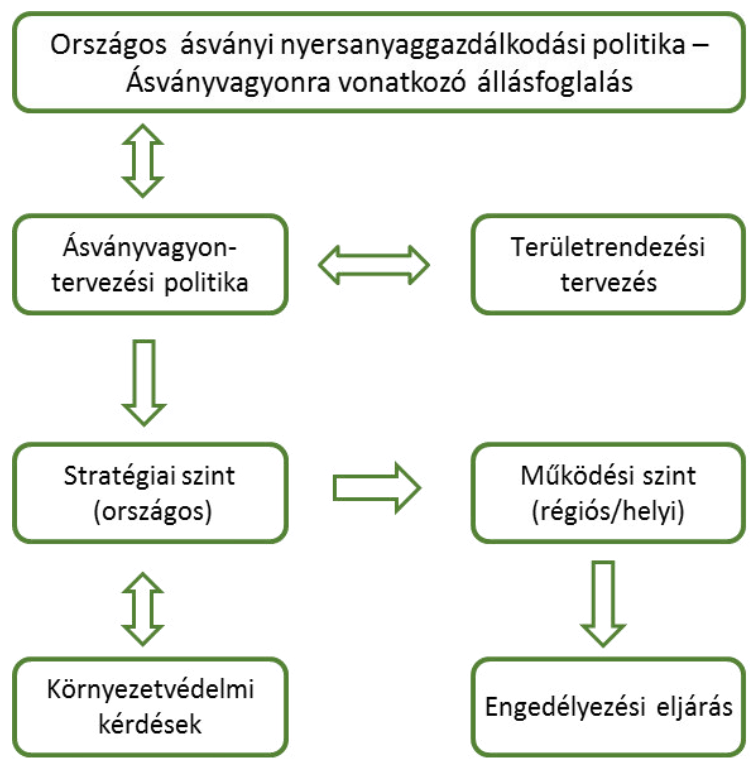

3.1. ábra: Országos ásványvagyon-tervezési politika (Tiess 2011a; EC 2010b).

„Az országos ásványi nyersanyag-gazdálkodási politika keretein belül először ki kell adni egy ásványvagyonra vonatkozó állásfoglalást. Ennek két alapvető témakört kell tartalmaznia az aggregátumokra vonatkozóan: az országos ásványi nyersanyaggazdálkodási politikának először fel kell hívnia a figyelmet a társadalom ásványi nyersanyagok iránti szükségletére, különösen az aggregátumokra vonatkozóan, valamint az aggregátumok esetén ki kell emelnie a helyi erőforrások hozzáférhetőségének szükségességét. A második, valóban kulcsfontosságú kérdés az ásványi nyersanyag-, és különösen az aggregátumellátás meghatározása úgy, mint a társadalmi 
jólét forrása, valamint az, hogy ez kiegyensúlyozott megközelítést határoz meg a kitermelés hatásvizsgálatára és a bányászati fejlesztésekre. Az országos ásványvagyon politikának figyelembe kell vennie az előrejelzett közép- és hosszú távú aggregátumkeresletet, biztosítva, hogy létezzen megfelelő helyi, hozzáférhető készlet, ami a helyi területfejlesztési tervezés részét képezi" (Tiess 2010, 15. o.).

A regionális tervezés lépése különösen szükséges a nyersanyagokkal kapcsolatos kérdések szabályozásához. Jól megalapozott állítások segítségével a regionális tervek (amelyek széleskörü (pl. országos és nagyrégiókra vonatkozó) fejlesztési programokon alapulnak) meghatározzák az egyes körzetekre lebontva a területrendezés regionális céljait. Az ásványi nyersanyagok védelmére és kitermelésére tervezett regionális területrendezési tervnek tartalmaznia kell egy pontos tervezési folyamatábrát és szöveges magyarázatot. A tervhez tartozó szöveges magyarázatban meg kell határozni a „elsőbbségi aggregátumzónákat”, amelyeket a közép- és hosszú távú ásványvagyon-kereslet és a ásványi nyersanyag-előfordulások korlátozott hozzáférhetőségének gondos figyelembe vételével védeni kell.

Az „elsőbbségi aggregátumzónák” kijelölése csorbítja a tulajdonjogokat, emiatt egyeztetések szükségesek az érintett földtulajdonosokkal. Igazolni kell, hogy közérdekről van szó, ami az aggregátumellátással/kitermeléssel kapcsolatos és arra érvényes, mivel az aggregátumok szükségesek a gazdasági fejlődéshez. Tisztázni kell azonban az erőforrások közép- és hosszú távú, mennyiségre, minőségre és alkalmazásra vonatkozó szükségességét. Egy terület „elsőbbségi aggregátumzónának” való kijelölését az aggregátumpiac szerkezetének vizsgálatával és anyagáram-elemzéssel kell igazolni.

Módszertani szempontból két különböző megközelítés használható a területrendezésnél. Az első megközelítés lényege, hogy adott területen bizonyos hasznosítások kizárásával korlátozzák a tervezést. E módszer hátránya, hogy a fenntartható aggregátumellátás, azaz a kiemelt aggregátumvagyon-területek rendszeres biztosítása nem lehetséges. A második, alternatív megközelítésnél az egyéb felhasználási prioritások területei csökkentik a kitermelésre érdemes előfordulásokat, míg a maradék területek elsődleges aggregátum ellátási területté válnak. E megközelítés előnye, hogy a hatóságok az esetlegesen előforduló földspekulációk ellenére tényleges aggregátumvagyon-gazdálkodási politikát tudnak kialakítani. Olyan hosszú távú terveket kell alkotni, amelyek figyelembe veszik az aggregátumkeresletet, az aggregátumhoz való hozzáférést, és a termékek teljes életciklusára előre jelzik a hatásokat (fenntarthatóság). A végső cél az ellátás biztosításának és az erőforrás-hatékonyság elérése. 


\subsection{A tervezési dokumentumok és módszerek tartalma}

Az aggregátumtervezésért felelős hatóságok országos és regionális szinten a bányászati, területrendezési és egyéb hatóságok. Hatáskörük (Trento autonóm tartomány kivételével) csak az elsődleges aggregátumokra terjed ki.

Öt országban (Albánia, Hercegboszniai kanton (Bosznia-Hercegovina), Horvátország, Szlovénia és Trento autonóm tartomány (IT)) az aggregátumtervezési dokumentumok törvényben vagy rendeletben vannak meghatározva. Az aggregátumtervezési dokumentumok a bányászati stratégia, bányatörvény és a koncessziókhoz kapcsolódó szabályozások. Más országokban (Magyarország, Románia és Szerbia) az aggregátumtervezési dokumentumok nincsenek előre meghatározva egy törvényben vagy rendeletben, mint pl. Ausztriában, ahol az AUT MINPLAN nincs jogi jellege.

A legtöbb SEE országban a terv fejlesztéséért felelős fő hatóság (koordinátor) a gazdasági minisztérium (ásványvagyonnak foglalkozó osztálya), szoros együttműködésben a nemzeti geológiai szolgálattal és a területrendezési hatóságokkal és egyéb minisztériumokkal, pl. környezetvédelmi és területfejlesztési (Területfejlesztési és Területrendezési Minisztérium).

A legtöbb országban az aggregátumterveket a közösség vagy a társadalom igényeitől függően 5-10 évenként frissítik, kivéve Albániát, ahol a bányászati stratégia 15 évet fed le, valamint a Hercegboszniai kantont, Szerbiát és Romániát, ahol a bányászati törvények nem foglalkoznak kimondottan az aggregátumtervek frissítésének gyakoriságával.

Általában az aggregátumtervnek a területrendezési terveken kell alapulnia. A területrendezési tervekbe integrált aggregátumtervek hosszú távon támogatják az iparágat és az érintett hatóságokat egy stabil aggregátumtervezési keretrendszer létrehozásában. Az egyéb földhasználati célokra kijelölt területek és az ásványi nyersanyaglelőhelyek egymást átfedő térképei segíthetnek kijelölni a potenciális konfliktusos területeket, így, amennyiben megvalósítható, a későbbi fejlesztések távol tarthatók ezektől a zónáktól.

\subsubsection{Miért kell az ásványi nyersanyag-kitermeléshez hatósági tervezés?}

A fenti kérdésre a legátfogóbb válasz a szlovéniai, érdekelt felekkel történő konzultáción hangzott el:

Az interaktív munkatalálkozó eredményei és a megbeszélések alapján a gyakorlat és a jogszabályok számos lehetséges módon módosíthatók a szlovén aggregátumellátás 
jobb működése érdekében. Ilyenek a nemzeti területfejlesztés és bányászati stratégia iránti igény, az építési hulladékok újrahasznosításával kapcsolatos jogi szabályozás fejlesztése, a különböző érdekelt felek nagyobb mértékű bevonása az aggregátumtervezési folyamatokba, a koncessziós jogok helyi közösségek/állam közti jobb elosztásának igénye, illetve a bányászatban és feldolgozásban a legjobb technológiák alkalmazásának fontossága.

\subsubsection{Hogyan tervezzék az aggregátumtervezési hatóságok az ásványi nyers- anyag-kitermelést?}

Az aggregátumtervezési hatóságoknak az alábbi módok valamelyikén kell megtervezniük a folyamatos és megfelelő aggregátumellátást (fontossági sorrendben).

1. Olyan területek kijelölése, ahol van ismert, mürevaló ásványvagyon, a földtulajdonos támogatja az ásványi nyersanyag-kitermelést, és a javaslatot valószínúleg elfogadják a tervezéskor. Az ilyen területeken esetleg az ásványi nyersanyag-kitermeléshez kapcsolódó alapvető múveltek is elvégezhetők.

2. Olyan, ismert ásványvagyonnal rendelkező területek kijelölése, ahol a kivitelezési engedély elfogadása várható. Az ilyen területeken esetleg az ásványi nyersanyag-kitermeléshez kapcsolódó alapvető műveltek is elvégezhetők. És/vagy

3. Olyan területek kijelölése, ahol az ásványvagyon talán kevésbé ismert, de ahol a kivitelezési engedély megadható, különösen, ha potenciális ellátási hiány áll fenn.

A tervezési folyamat, múködési/engedélyezési eljárás SARM követelményei tartalmazzák a hosszú távú tervezés igényét, így megfelelő időt biztosítanak egy új bányászati tevékenység létrehozásához szükséges befektetés megtérüléséhez. A SEE partnerországokban országos szinten a legátfogóbb ásványvagyon-gazdálkodási terv az Osztrák Ásványvagyon-gazdálkodási Terv (AMRP) (2010), amelyet a regionális kormányzatokkal szoros együttmúködésben alakítottak ki. Az ásványvagyongazdálkodási tervek Horvátországban (Országos Ásványvagyon Tervek), Szlovéniában (Országos Program az Ásványvagyon Gazdálkodásért-NPMRM) és Trento autonóm tartományban (IT) a következő alapelveket követik (Cibin et. al. 2011):

1. Aggregátumkereslet és -kínálat forrásai: az előrejelzésbe ajánlott bevenni a részletes aggregátumpiaci és anyagáram elemzésen alapuló, várható aggregátumigényt. Ha lehetséges a vizsgálatokba be kell vonni az anyagok végső, tervezett felhasználását (különböző betonok, töltőanyagok, útalapok, útburkolatok stb.).

2. Aggregátum-hozzáférhetőség: az ellátási tervnek tartalmaznia kell a természetes és alternatív aggregátumok lelőhelyeit. Tartalmazniuk kell az összes lehetséges alternatív forrást, és a lelőhelyeket minőség szempontjából kell 
besorolni. Ajánlott megvizsgálni a nem megújuló készletek várható kimerülését, amelyeket ki kell termelni az előre jelzett kereslet kielégítése érdekében. A cél ennek az értéknek a minimalizálása.

3. Lehetséges hatások: szükséges minden helyi hatás (zaj, levegő, vízkészletek, biodiverzitás stb.) számszerüsítése; vizsgálni kell az elsődleges kereskedelmi útvonalakat, amelyeket a szállításra fognak használni, illetve vizsgálni kell a szállítás hatását ezekre az utakra.

4. Életciklus-vizsgálat: fontos az aggregátumok végső célja (újrahasznosítás/ártalmatlanítás) az életciklusuk végén, valamint a külfejtés helyreállításának módozatai a kimerülés után.

5. Forgatókönyvek (kereslet/kínálat): többféle megközelítést kell figyelembe venni az aggregátum kereslet kielégítésénél.

Ahogy azt jeleztük a Bevezetésben, az építőipari ásványi nyersanyagtelepek (azaz aggregátumtelepek) három fő tulajdonsággal bírnak: helyhez kötöttek, regionálisan használhatók fel, és kimerülésre hajlamosak. E tulajdonságok miatt a telepek létezését, valamint azok kiterjedését és összetételét minél hamarabb meg kell határozni. $A z$, hogy egy telep a későbbiekben használható-e vagy sem, a megfelelő szempontok figyelembe vételével készült területrendezéstől függ. A telepekre vonatkozó, időszakos és teljes információk segítenek a lehetséges területrendezési konfliktusok megoldásában. A fenti pontok tartalmazzák az aggregátumellátási terv kifejlesztéséhez szükséges tudásbázist. A leghatékonyabb és legmegfelelőbb ezen adatok legmagasabb (stratégiai) szintű (régiós vagy országos) összegyújtése lenne, majd eztán átvinni azokat helyi szintre (a megfelelő hatóságok számára). Ez alapvető fontosságú lesz az aggregátumpiacok közép- és hosszú távú fejlesztésének folyamatos ellenőrzésekor, illetve a szomszédos régiók terveiben lévő eltérések csökkentésénél (Cibin et. al 2011).

Példa: A Regionális Ásványvagyon-gazdálkodási Terv (Horvátország) tartalma

1. Ásványvagyon-potenciál földtani térképei (méretarány: 1:10 0001:100 000)

2. Ásványvagyon-lelőhelyek adatbázisa

3. Bányászati területek

4. Termelési és készletadatok

5. Környezetvédelmi feltételek és korlátozások

6. Piaci és fejlesztési igények

7. Helyreállítási ajánlások

8. Kitermelési célra legkedvezőbb lehatárolt területek (ásványvagyonnal rendelkező, földhasználati konfliktustól mentes területek).

9. Érdekelt felek véleményei az ásványvagyon-politikáról (helyi hatóságok, gazdasági szereplők, civil szervezetek, önkormányzatok) 
Példa: Az Osztrák Ásványvagyon-gazdálkodási Terv

Az Osztrák Ásványvagyon-gazdálkodási Terv (AMRP) kijelöli azokat az aggregátumzónákat, amelyek lényegesek (lehetnek) a regionális tervezési folyamatoknál: minden területrendezési törvény figyelembe veszi az úgynevezett elsőbbségi aggregátumzónákat, melyeket óvni kell egyéb fejlesztési/felhasználási céloktól. Ezek a zónák az AMRP-n alapulnak, és be kell épülniük a regionális területrendezési tervekbe (folyamatban van). Mivel a regionális terveket a helyi önkormányzatoknak kell elfogadniuk, ezek az elsőbbségi aggregátumzónákat - amelyeket a regionális tervek tartalmaznak - szintén el kell fogadniuk a helyi önkormányzatoknak (tervezési hierarchia). Ha egy gazdasági szereplő aggregátumot kíván kitermelni, hivatkozhat ezekre a zónákra.

(lásd még: 3.2.3 fejezet példái)

\subsubsection{Földtan és aggregátumpotenciál}

A SEE országok tervezési dokumentumaiban különböző léptékű földtani (potenciál) térképek léteznek, országos szinten 1:500 000-től (Magyarország - Országos Területrendezési Terv, Románia) a legérdekesebb területeken 1:50 000-ig (Románia, Magyarország - az ásványvagyon gazdálkodásra kijelölt területek helyszínrajzai az Országos Területrendezési Terv részei, és a bányatelkeket megjelölik az országos és helyi területrendezési tervekben), valamint Trento autonóm tartományban a tartományi földtani térképek léptéke 1:10 000. Albánia földtani térképe különböző méretarányokban készült el, pl. 1:200 000, 1:50 000 és 1:25 000. Területének csaknem 75\%-a 1:10 000 méretarányú földtani térképen van megjelenítve. Ausztriában a teljes országra vonatkozó adatok elérhetők 1:50 000-es méretarányban. Horvátországban csak korlátozottan léteznek földtani adatok, a területrendezési tervekben a lépték 1:100 000 (Regionális Területrendezési Terv). Szlovéniában a földtani adatok a Bányászati Közszolgáltatóhoz tartoznak, amely a Geológiai Szolgálattal közösen nyújt áttekintést, szakvéleményt és útmutatást (amik az elérhető földtani adatokon alapulnak, beleértve az adatbázisokat és a földtani térképeket) a területrendezési hatóságok számára. Szerbiában léteznek földtani alapadatok és néhány általános ásványvagyon térkép, de ezek nem részei a területrendezési terveknek. Az országok nagy részében az adatok térinformatikai rendszerben vannak kezelve, ami a jövőre nézve biztosítja, hogy a számítások és a kalibrálások valamint a finom beállítások nagy része automatikus, és az eredmények hitelessége bármikor ellenőrizhető.

Az ásványi nyersanyag csak a természetes előfordulási helyén bányászható, így korlátozottak lehetnek a gazdaságilag mürevaló és környezetvédelmileg elfogadható bányatelkek. Ez azt jelenti, hogy figyelembe kell venni minden, aggregátumelőfordulásokra vonatkozó, országos és regionális léptékű, földtani információt (tér- 
képeket, jelentéseket stb.). Az Osztrák Ásványvagyon-gazdálkodási Terv (AMRP) alapelvei követendő példát jelentenek egy aggregátumtervezési dokumentum földtani kereteinek elkészítésekor. A Földtani Térképezési Programoktól függően, országonként eltérőek lehetnek a területrendezési értékelések földtani térképei. A SEE országokban a regionális skála 1:25 000 és 1:50 000 között változik.

Példa: Homok- és kavicstérképek

A homok- és kavics-előfordulások értékelése az osztrák (AMRP) paleogén, neogén és negyedidőszaki üledékek 1:50 000 méretarányú összesített térképe alapján készült. Ez a térkép megmutatja a konszolidálatlan üledékek fácieseit, és információkat nyújt a legfontosabb kőzettani tulajdonságokról. Hasonló megközelítés alapján készülnek a 1:100 000 méretarányú térképek Horvátországban is.

A homok- és kavics-előfordulások értékelése a nyersanyag mennyisége, minősége, valamint az előfordulás helyi vagy regionális ellátásban való jelentősége alapján történik. Ezt a három szempontot egy 3D mátrixba rendezik, hogy ebből következtessenek a térinformatikai (GIS) rendszerben a homok és kavics földtani alkalmasságára. A nyersanyagok minőségi vizsgálata két tényezőn alapul: (1) az anyag kőzettani leírása és (2) a nyersanyag felhasználási területe.

Az üledéktest földtani potenciáljának kiszámításához a nyersanyag mennyiségét és minőségét viszik fel az első mátrixba. Különböző mátrixot használnak a síkvidéki és hegyvidéki területek potenciáljának számításához, így figyelembe tudják venni az egyedi regionális földtani jellemzőket, különösen a magashegyi völgyek kis előfordulásait, melyek csak a helyi ellátást szolgálják, de ugyan olyan fontosak lehetnek, mint a jelentősebb városok közelében lévő, nagy előfordulások. Az eredményül kapott öt lépcsős potenciálminősítés megadja az építőanyagként használható homok és kavics üledéktestek relatív kapacitását.

Példa: Zúzott kő/terméskő térképek

Az előfordulások és telepek földtani osztályozását Ausztia 1:200 000-es, és ahol elérhető, 1:50 000-es, földtani térképei alapján végezték. A bányatelkek felmérését a Geológiai Szolgálat digitális katalógussal és keresési rendszerrel ellátott külfejtési nyilvántartása , a bányatelkek rendszeresen frissített adatbázisa alapján végezték.

Az építőiparban és a mélyépítési munkálatoknál egyaránt használnak zúzott termékeket (zúzott kő, kőtörmelék, jó minőségű kőforgács, zúzott homok) és díszítő köveket. A szilárd kőzeteket (1) magmás, (2) metamorf és (3) üledékes kőzetekre osztják. Minden ilyen nyersanyag-előfordulás esetén bizonyított a felderített vagy feltárt ásványvagyon (tágabb értelemben vett nyersanyagterületek), vagy a kitermelési területként való használat (általában külfejtések, ritkán mélymüvelésű bányák). 


\subsection{4 Ásványi nyersanyag-/aggregátum-nyilvántartás}

Ásványi nyersanyag-/aggregátum-nyilvántartás a legtöbb SEE országban létezik a Hercegboszniai kanton (Bosznia-Hercegovina) és Szerbia kivételével. A többi SEE országban van nyilvántartás, és a bányatelkek minden adatát tartalmazza: GIS koordináták, telekméret, nyersanyagtípus, tevékenység módja (feltárás, kitermelés), készlettípusok, a készletek mennyisége, a nyersanyag minőségi adatai, pl. hasznos ásványi nyersanyagtartalom százalékban megadva.

Az elsődleges aggregátumvagyon, készlet és termelési adatok az ásványi nyersanyag térinformatikai rendszer részeként ideális esetben az alábbiakat tartalmazzák:

1. A bányatelek méretére és alakjára vonatkozó térbeli adatok

2. Bizonyított készletek

3. Az aggregátum típusa és minősége

Az adatokhoz való hozzáférés a nyilvánosság számára a legtöbb országban korlátozott azok bizalmas volta miatt, de általában évenként összegyújtik azokat a bányászati hatóságok.

\subsubsection{Másodlagos aggregátum-nyilvántartás}

A legtöbb SEE országban szegényes a másodlagos aggregátumok nyilvántartása. Általában a környezetvédelmi minisztérium vagy ügynökség biztosít adatot a hulladékokról (C\&D hulladék, bányászati hulladék, másodlagos aggregátumok), a Hulladéktörvénnyel, vagy hasonló törvénnyel összhangban. Négy SEE partnerországban nincs másodlagos aggregátum-adatbázis, -nyilvántartás, vagy csak valamiféle összegyújtött adattal rendelkeznek a másodlagos aggregátumokról (Hercegboszniai kanton (Bosznia-Hercegovina), Szerbia, Albánia és Románia.

Példa: Trento autonóm tartomány (IT)

A C\&D hulladékterv az alábbiakat tartalmazza:

1. Egy műszaki jelentést az alábbiakkal:

a. Kezelendő hulladékok típusai és mennyisége

b. Kezelési módszerek

c. Felhasználói bázis mérete

d. Szervezeti kritériumok és gazdálkodás

2. Az ártalmatlanító és újrafeldolgozó üzemek elhelyezkedése és ezen üzemek elhelyezésére megfelelő területek 
3. Területek kijelölése ártalmatlanító és újrafeldolgozó üzemek céljaira, a tartományi városrendezési és egyéb, a tervezési hierarchiában ide illő tervek előírásaival és előrejelzéseivel összhangban.

4. Az üzemek tervezésére, üzembe helyezésére és múködtetésére vonatkozó kritériumok és műszaki előírások.

5. Az üzemek elérésének meghatározása.

6. A terv tartalmának megvilágítását segítő, megfelelő méretarányú ábrák.

A tartományi bányászati szolgálat felelős a külfejtési tervért, és készíti el azt. Az APPA (Tartományi Környezetvédelmi Ügynökség) felelős a C\&D hulladéktervért, és készíti el azt. Mindkét esetben általában szükséges az egyéb közszolgáltatók és érdekelt felek segítsége, pl. geológiai szolgálaté és a bányászati szövetségé. Külső szervezetek, mint szakmai múhelyek, bevonhatók a tervkészítésbe közbeszerzési eljárás keretében, pl. a C\&D hulladékkezelési terv külső szakértő bevonásával készült. A terveket a tartományi kormányzat jóváhagyása teszi kötelezővé.

Példa: Újrahasznosított aggregátumok nyomon követésének módszertana (Ontario, Kanada)

A közhivatalokban végzett felmérések és a hasonló nemzetközi rendszerek áttekintése alapján Ontarióban a következő módszert ajánlják az újrafeldolgozott aggregátumok nyomon követésére:

1. Útmutatót kell készíteni arról, hogy hogyan és milyen anyagokat kell követni annak érdekében, hogy a tartományból származó adatok szabványosítva kerüljenek a rendszerbe.

2. Egy online számítógépes adatbázist kell létrehozni a közhivatalok számára, hogy rögzíthessék az újrafeldolgozott aggregátumok hasznosítására vonatkozó információkat.

3. Ahhoz, hogy a közhivatalok képesek legyenek ellátni ezt a plusz feladatot, további pénzügyi támogatásra, személyzetre és képzésre lesz szükségük.

4. A közhivatalok plusz feladatainak elszámoltathatósága érdekében a finanszírozást az adatok megfelelő rögzítésének függvényévé kell tenni.

5. Az újrafeldolgozás társadalmi hasznának megismertetése érdekében évi jelentés füzeteket kel készíteni, melyek kiemelik a tartományban az újrafeldolgozott aggregátumok felhasználásához kapcsolódó sikereket és lehetőségeket.

Forrás: Ontariói Természeti Erőforrások Minisztériuma (2010) 


\subsubsection{Aggregátumgazdaság}

A legtöbb SEE partnernél nincsenek az aggregátumfogyasztási és -termelési trendekre vonatkozó statisztikai adatok, modellek vagy előrejelzések. Csak Trento autonóm tartomány rendelkezik építési volumenre vonatkozó adatokkal, de jelenleg nem használnak modellt.

Az aggregátumgazdasági elemzésnek a Fenntartható kínálati mix (SSM) fogalmán kell alapulnia. Az SSM több forrást használ, amik együttesen maximálják több generáción keresztül az aggregátumok tiszta hasznát (Shields et. al, 2006). Az SSM tervezés a fenntartható aggregátumellátás biztosítása érdekében az ezeket az összetett forrásokat használó érdekelteken/hatóságokon keresztül kapcsolódik a tervezési/fejlesztési folyamathoz. Minden kapcsolódó érdekelt félnek (pl. a területrendezés, az újrafeldolgozott aggregátumok tervezési folyamatai szabályozásának és a természeti erőforrások fenntartható felhasználásának felelőseinek) szoros együttmúködésben kell dolgozni. Az SSM tervezési keretrendszer „alapvető múködési szabályokat” nyújt az elsődleges és másodlagos aggregátum-iparág számára. Az aggregátum-iparág maga felelős a teljes bányászati életciklusért, beleértve a feltárást, a kitermelést, a feldolgozást és a terület helyreállítását, és ennek megfelelően kell megtervezniük az üzleti tevékenységüket. Felvetődik egy kérdés (társadalmi vonatkozások), hogy miIyen mértékben kell bevonni a piaci szereplőket és a hatóságokat az SSM tervezési folyamatba. Például a piaci szereplők gyakran nem elégedettek a föld árak tekintetében a kiválasztott elsőbbségi aggregátumzónák műszaki prioritásaival.

\section{Példa: Aggregátumpiac}

Elkészült az USA keleti részének aggregátumpiaci modellje, és mérték az összetevőinek kapcsolódásait. Az aggregátumkereslet, -kínálat és -szállítás szisztematikus tanulmányozásával azonosították be a megfelelő modellparamétereket. A kínálati modell alapjai a termelési adatok. A kereslet megbecsüli a teljes fogyasztást az egy före jutó kibocsátás és a részesedési arányok alapján. Az ár főleg a földtani hozzáférhetőség, piac méretének, a műveletek méretének és az éves, egy före jutó átlagnak a függvénye. Az elosztás a legkisebb költség, amely a szállítási költségek korlátozásával egyensúlyt teremt a termelés és a fogyasztás közt.

Bár az árak országról országra változnak, az aggregátumok viszonylag olcsó termékek. Az ipari profit árrések általában nagyon szorosak, és az aggregátumszektor gyakran nagyon érzékeny bármilyen külső, közvetlen vagy közvetett tényezőre, amely befolyásolhatja az árakat. Az aggregátumok nagy terjedelműek, általában a kitermelési helyhez közeli piacokon veszik fel őket. A szállítás az ellátási folyamat kulcseleme, és jelentős részét képezi a fogyasztói árnak. Egy aggregátumot szállító teherautó költsége megduplázódik, ha 40 km-re szállítja az árut. Az aggregátumellátás és - 
gazdálkodás koncepciójának részletes aggregátumpiaci elemzésen, anyagáramelemzésen és trendvizsgálatokon kell alapulnia. Ezek kapcsán fontos különbséget tenni a fogyasztás és a termelés, valamint a belső (helyi/regionális) és külső (régiók közti/régiókon túli) aggregátumellátás között. Egy SSM politikai keretrendszernek az aggregátum-iparág számára biztosítania kell a szükséges támogatást, pl. a terület hozzáférhetősége, szállítási logisztikához szükséges információk.

Forrás: Poulin, Bilodeau (1993)

\subsubsection{Területfejlesztés és környezetvédelmi hatások}

A legtöbb SEE partnerországban léteznek a kitermelési területek azonosítására szolgáló eljárások és kritériumok. Néhány országnak jól meghatározott feltételei vannak. Az osztrák területrendezési keretrendszer nagyon összetett és bonyolult, míg Trento autonóm tartományban két vizsgálati eszköz van: ágazatok közti bizottság és az EIA (környezetvédelmi hatásvizsgálat). Az EIA minden országban kötelező, minden bányászati tevékenység, és egyéb, környezethez kapcsolódó beavatkozás esetén. Néhány országban nem megfelelő a hatóságok közti együttműködés a környezetvédelmi kritériumok, az átmeneti zóna és a szállítás tekintetében.

Az aggregátumtervezési hatóságokhoz kapcsolódó fő kérdések, melyekkel a tervezési dokumentumoknak foglalkozniuk kell, figyelembe véve, hogy nem minden kérdéskör érvényes azonos mértékben az egyes területeken, az alábbiak:

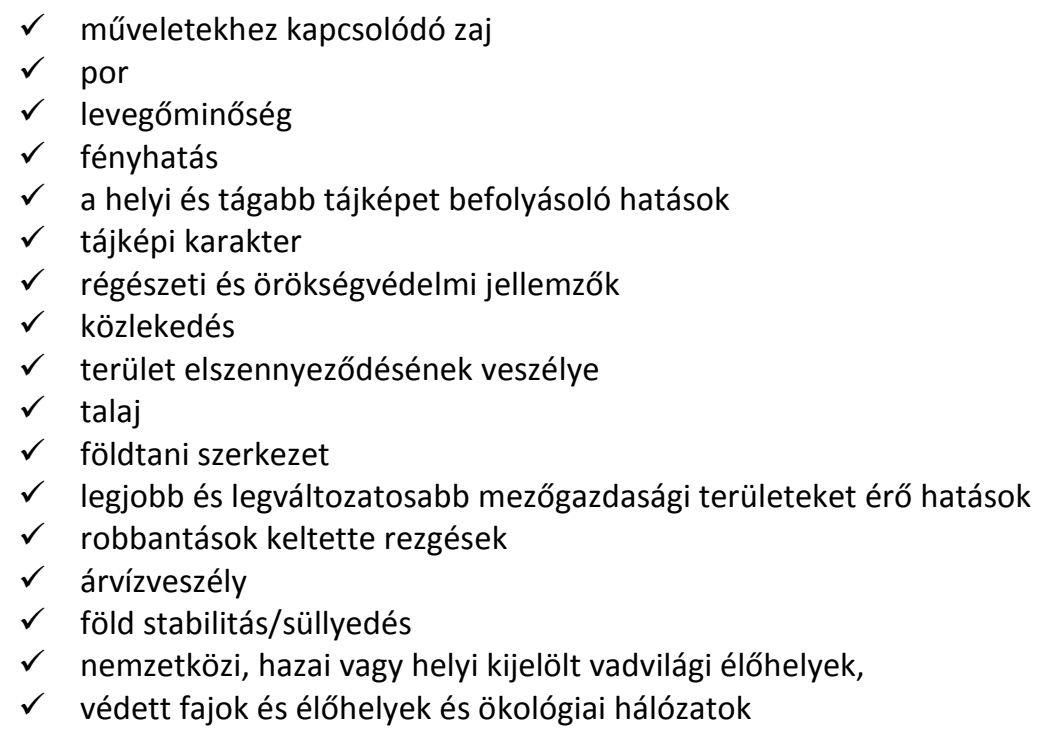


$\checkmark$ nemzeti védett tájakat (nemzeti parkokat) érő hatások

$\checkmark$ országosan védett, földtani és geomorfológiai területek és jellegzetességek

$\checkmark$ a terület helyreállítása és utógondozás

$\checkmark$ a felszíni, és néhány esetben a felszín alatti vízhez kapcsolódó kérdések

$\checkmark$ vízkivétel.

Példa: Szállítási kérdések és környezeti hatások

Az osztrák Ásványvagyon-gazdálkodási Terv 2. fázisában az 1. fázisban azonosított és feltérképezett nyersanyag-területeket digitálisan összedolgozzák azon regionális fejlesztési tervekkel, amelyek tiltják vagy korlátozzák a nyersanyag-kitermelést (konfliktus megszüntetése). A felszín közeli nyersanyagok esetén a terülteket igény szerint választják ki. Erőfeszítéseket tettek a gyártó és a fogyasztó közti távolság minimalizálására. A szállítási távolság $10 \%$-os csökkentése az évi $\mathrm{CO}_{2}$ kibocsájtást több mint 1 millió tonnával csökkentheti. A szállítás rezgést, zajt és port von maga után, ami gyakran elkerülhetetlen. Az üzemeletetők megpróbálnak megfelelő útvonalakat találni ahhoz, hogy a legkevesebb szomszédot zavarják vele. Ez gyakran megnöveli a szállítási távolságot.

\subsubsection{Módszertani eljárás - aggregátumvédelem/-kitermelés és területrendezés}

Az osztrák Ásványvagyon-gazdálkodási Terv keretei között egy olyan hatékony módszertant fejlesztettek ki a Joanneum Kutatóintézetben, amely az ásványvagyon kitermelése során előforduló konfliktusokat vizsgálja (3.2 ábra). Az eljárás alapja a különböző tematikus térképek, úgynevezett természeti potenciáltérképek használata, amelyen a nyersanyag-kitermelés érdekeit szem előtt tartva bizonyos információkat céltudatosan kiválasztottak és egymással átfedésbe hoztak. A különböző hasznosítási területek tematikus átfedésével kijelölnek bizonyos konfliktusokat, amelyeket prioritás alapján rangsorolnak, végül megoldanak.

A hatásvizsgálat lépései az értékelés során:

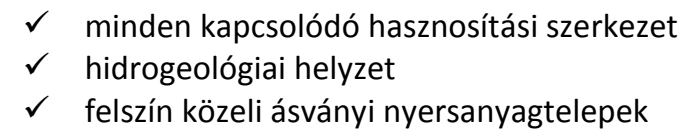

Tematikus térképek sorozata jött így létre, amely a tervezéshez szükséges jelentős információkat és paramétereket tartalmaz. Ezekre alapozva a nyersanyag-kitermelés szempontjából úgynevezett „pozitív-negatív területeket” jelöltek ki a döntéshozók számára. A térképek elkészítésénél használt módszernek és alapelvnek két fő célja volt: először egy átlátható és rugalmas rendszer létrehozása a tervezők számára az új információk bevitelének céljára és az új termékek azonosítására, másodszor alapot 
teremteni egyéb tervezési célok számára, hogy a térképi rendszer a lehető legsokoldalúbbá váljon.

1 és 2 típusú aggregátumzóna (az Osztrák Ásványvagyongazdálkodási Terv alapján) regionális/régiók közti hatáskörrel

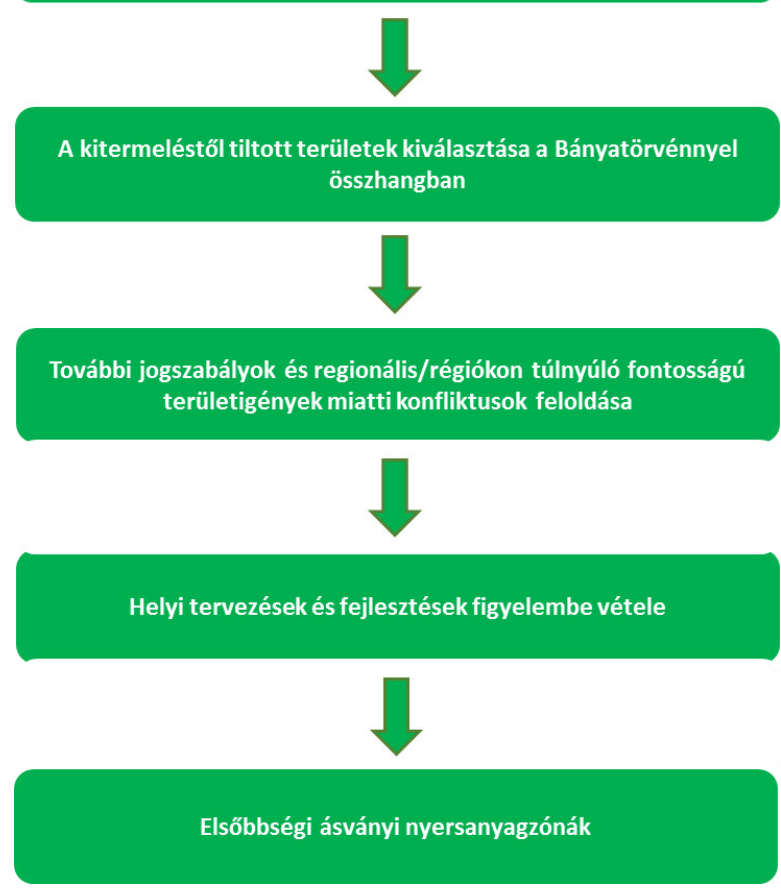

3.2. ábra: Az osztrák Ásványvagyon-gazdálkodási Tervben alkalmazott módszer (országos és regionális tervezési szintek figyelembe vételével)

Az elsőbbségi ásványi nyersanyagzónák térbeli lehatárolása és elemzése az alábbi lépésen alapul:

1. A bányatörvény (82. cikkely) szerint bányászattól elzárt területek kihagyása: lakott területek (beleértve a központi területeket is), 300 m-es védőtávolság, további beépített területek, vízvédelmi területek és védett területek;

2. Konfliktuskezelés adott területigények esetén, pl. elsődleges mezőgazdasági zónák, zöld zónák, valamint egyéb jogszabályokhoz kapcsolódó korlátozások (vízbázisvédelmi és erdészeti területek);

3. Konfliktuskezelés a helyi területrendezés, ártéri területek és a közúti szállítás tervezése esetén. 
A földtudományi módszerek felhasználásával készített alkalmassági zónák térképeit digitálisan fedésbe hozták a tartományi kormányzatok által nyilvánosságra hozott regionális tervezési adatokkal. Az adott regionális tervezési részleteket úgynevezett tiltott és konfliktusos zónákra bontották. Azok a tiltott zónák, ahol szövetségi vagy tartományi törvény tiltja az ásványi nyersanyag kitermelését. Konfliktusosként azokat a zónákat jelölik, ahol korlátozzák a kitermelést. Ilyen területek például a Natura 2000 területek, ahol nyersanyag-kitermelés csak akkor végezhető, ha pozitív eredményt ad a környezeti hatásvizsgálat. Az egyes tartományokban mind tartalmi, mind hatásköri szempontból nagyon eltérően határozzák meg a konfliktusos zónákat.

Az alkalmassági zónák térképezésével kapott, a tiltott zónákat tartalmazó eredményekre 1. forgatókönyvként hivatkoznak. Következésképpen a konfliktusos zónákat kihagyták, és a maradék területeket jelölik 1. forgatókönyvként. E maradék területek alapvetően olyan ásványi nyersanyagterületek, ahol nincsenek konfliktusok, de amelyeket még részletesen át kell vizsgálni, különösen a számos maradék területet illetően, amelyek vagy túl kicsik a gazdaságilag hasznosuló kitermeléshez, vagy más okok szólnak a jövőbeli kitermelés ellen (pl. szélerőmúparkok, elektromos távvezetékek, gázvezetékek stb.).

\subsubsection{Védőtávolságok/átmeneti zónák}

A védőtávolságok/átmeneti zónák bizonyos körülmények esetén megfelelőek lehetnek, ha bizonyos hatásvizsgálatok és egyéb kárenyhítési intézkedések (pl. munkafolyamat-tervezés és tájrendezés) alapján egyértelmü, hogy bizonyos távolság szükséges a bányatelek határa és lakott területek között. Minden javasolt védőtávolságot területspecifikusan kell kialakítani, hatékonynak, megfelelően indokoltnak és ésszerűnek kell lennie. A következőkre kell tekintettel lenni:

\footnotetext{
$\checkmark \quad$ az ásványi nyersanyag-kitermelési tevékenység természete

$\checkmark \quad$ kerülni kell az ásványi nyersanyag-előfordulások indokolatlan nem kitermelési célú felhasználását

$\checkmark$ elhelyezkedés és topográfia

$\checkmark$ a felmerülhető, különböző környezeti hatások jellemzői

$\checkmark \quad$ az alkalmazható, különböző kárenyhítő intézkedések
}

Miután a két forgatókönyv maradék területeit egyesítették ebben a finomhangolási eljárásban, elvégezhető a térfogati elemzés.

Az osztrák Ásványvagyon-gazdálkodási Terv (AMRP) - ahogy már korábban említettük - kapcsolódik a regionális területrendezési tervekhez. A területrendezési jogszabályokon és (regionális szintű) fejlesztési programokon alapján készülnek a regionális 
tervek, amelyeknek meg kell jelenniük a helyi területrendezési tervekben. Az ásványvagyon kitermelését és védelmét szolgáló regionális területrendezési tervnek tartalmaznia kell egy pontos tervezési ábrát és szöveges magyarázatot. A tervhez tartozó szöveges magyarázatnak meg kell határoznia az „elsőbbségi ásványi nyersanyagzóna” fogalmát, így ezek a területek bányászati céllal jelennek meg a terveken, ahol garantálni kell az ásványvagyon kitermelést közép- és hosszú távú ásványi nyersanyagigények és az ásványi nyersanyagtelepek korlátozott hozzáférhetőségének gondos figyelembe vételével (utalva a helyreállítás témakörére is).

\subsubsection{Elsőbbségi aggregátumzónák elemzése}

Ausztriában az elsőbbségi aggregátum zónák vizsgálatának alapjai:

1. A bányatörvény (82. cikkely) szerint bányászattól elzárt területek kihagyása: lakott területek (beleértve a központi területeket is), 300 m-es védőtávolság, további beépített területek, vízvédelmi területek és védett területek;

2. Konfliktuskezelés adott területigény esetén, pl. elsődleges mezőgazdasági zónák, zöld zónák, valamint egyéb jogszabályokhoz kapcsolódó korlátozások (vízbázisvédelmi és erdészeti területek);

3. Konfliktuskezelés a helyi területrendezés, ártéri területek és közúti szállítási tervezés esetén.

\subsubsection{Társadalmi vonatkozások}

A legtöbb SEE partnerországban létezik kötelező közmeghallgatás az engedélyezési eljárás során, így az érdekelt feleket bevonják a területrendezési tervezésbe. Néhány országban a társadalmi vonatkozásokat a földtani jelentésben, bányászati tervben és dokumentációban megjelenő szakértői véleménnyel kezelik (Szerbia, Románia és Szlovénia). Az aggregátumtermelést azonban nem értékelik többtényezős, a különböző érdekelt felek preferenciáit alapul vevő elemzésen alapuló módszerekkel.

\subsubsection{Helyreállítás és hasznos utófelhasználás}

A legtöbb SEE partnerországban egy bányászati cégnek az aggregátumtermelés engedélyeztetése során kötelező kidolgoznia egy helyreállítási tervet. Ezt előírja a bányatörvény, az Országos Ásványvagyon-gazdálkodási Program általános tervének része, amely általános útmutatást tartalmaz a helyreállításról, vagy a Regionális Fejlesztési Program. A gondot az inaktív (felhagyott) bányatelkek jelentik. Trento autonóm tartományban a helyreállítás nélküli, felhagyott bányaterület nem felel meg a jogi gyakorlatnak, de ebben az esetben az önkormányzat felelős a helyreállításért, felhasználva akár a kaucióként kapott pénzt: valójában a bányavállalkozásnak vissza 
kell fizetnie az összes, hiányzó helyreállítási költséget az önkormányzatnak, és, ha a cég csődbe megy, elveszíti a letétet az önkormányzat javára.

A bányászati hatóságok (bányakapitányságok) ellenőrzik, hogy a termelés megegyezik-e a vállalkozó jelentésében foglaltakkal. A bányászati hatóság ellenőrzi a véletlenszerüen vagy bejelentés alapján kiválasztott külfejtéseket. A bányatelkek helyreállításának és utókezelésének felelősségét, beleértve a pénzügyi felelősséget, a bányavállalkozó, mulasztás esetén pedig a földtulajdonos viseli.

A terület-helyreállítás legmegfelelőbb formája a különböző utóhasznosítás elősegítése, amelyekkel mind a helyi ásványvagyon-gazdálkodási tervekben, - amely tartalmazza a munkaterület lehető leghamarabb történő, magas színvonalú visszaállításának politikáját -, mind a bányavállalkozó és az ásványvagyon-tervezési hatóság közötti, a területről területre történő párbeszédben foglalkozni kell.

A helyreállítás és utókezelés részletességének elvárt szintje az egyes területekre jellemző körülményektől, pl. a területen folyó műveletek várható időtartamától függ. Megfelelőnek kell lennie ahhoz, hogy egyértelmüen igazolja, hogy a terv átfogó célja a gyakorlatban elérhető, és normál esetben tartalmaznia kell az alábbiakat:
$\checkmark$ átfogó helyreállítási stratégia, megjelölve a terület javasolt utóhasznosítását
$\checkmark$ talajra és vízföldtanra vonatkozó információk, hogyan kezelik a ta- laj/altalaj/fedőréted/talajalkotó anyagokat a kitermelés során
$\checkmark$ mezőgazdasági terület esetén a mezőgazdasági területi besorolás hatásvizs- gálata
$\checkmark$ tájkép stratégia

Ha a munkálatok a legjobb és legsokoldalúbb mezőgazdasági területek egyikén folynak, a stratégiának körvonalaznia kell, ahol lehetséges, hogy a helyreállítási és utókezelési módszerek hogyan teszik lehetővé, hogy a földterület hosszú távon megőrizze eredeti képességét, bár a tervezett utófelhasználásnak nem kell minden esetben mezőgazdaságinak lennie.

Az ásványvagyon-kitermelés, helyreállítás és utókezelés befejeztével számos lehetséges területhasználati mód létezik:
$\checkmark$ új élőhely és biodiverzitás kialakítása
$\checkmark$ mezőgazdasági hasznosítás
$\checkmark$ erdészet
$\checkmark$ szabadidős tevékenységek
$\checkmark$ hulladékkezelés, beleértve a hulladéktárolást is 
$\checkmark$ épített környezet, mint lakó, ipari és kereskedelmi, ahol ez megvalósítható 


\section{Az aggregátum tervek optimális tartalmának közös jövőképe}

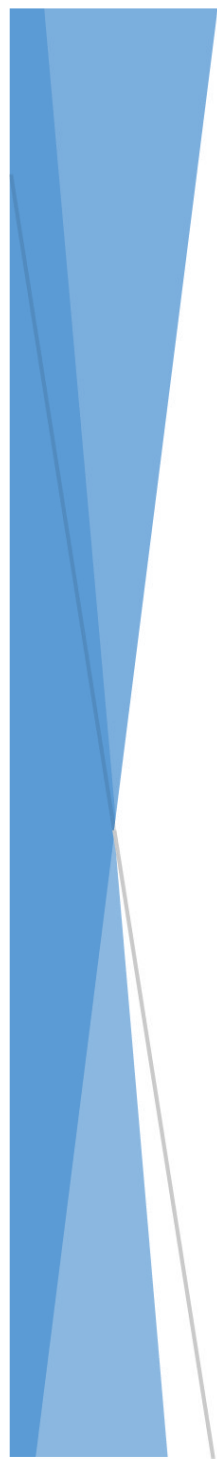

A nyersanyagokhoz való megbizható és zavartalan hozzáférés biztosítása az EU gazdasági versenyképességének növekvő fontosságú tényezője. A Nyersanyag-politikai Kezdeményezés (amit az Európai Bizottság 2008 novemberében fogadott el) egyik alappillére megadja a megfelelő uniós keretfeltételeket az Európán belüli forrásokból származó, fenntartható ellátás elősegítése érdekében (EC Guidance, 2010).

Az aggregátumtervezés legfontosabb szempontjai (a SEE régión kívül, pl. brit tervezés, SEE régión belül pl. Ausztria) a kiegyensúlyozottság és a fenntartható ásványi nyersanyagpolitika. Két dolgot kell összeegyeztetni: a társadalmi igények feltételeit, valamint a társadalmi jólétet nem lehet veszélyeztetni.

Ez egy fontos kihívás a 13 SEE ország számára, és emiatt alapvető fontosságú a másodlagos nyersanyagok hatékony felhasználása. Jelen közös jövőkép egyaránt szükséges az országos, nemzetközi és EU-regionális stratégiák kifejlesztéséhez és müködtetéséhez. 


\subsection{Bevezetés}

A közös jövőkép a multiszektorális elemzés eredményeire, aggregátumtervezési útmutatóra, az érdekelt felekkel való konzultációk tapasztalataira, a SWOT analízisre (fóképp a Brit Geológiai Szolgálat szerint), a SARMa (Fenntartható Aggregátumkészlet-gazdálkodás) ajánlásaira és egyéb szempontjaira (pl. SIP EIP RM 2013) alapozva készült (4.1 ábra).

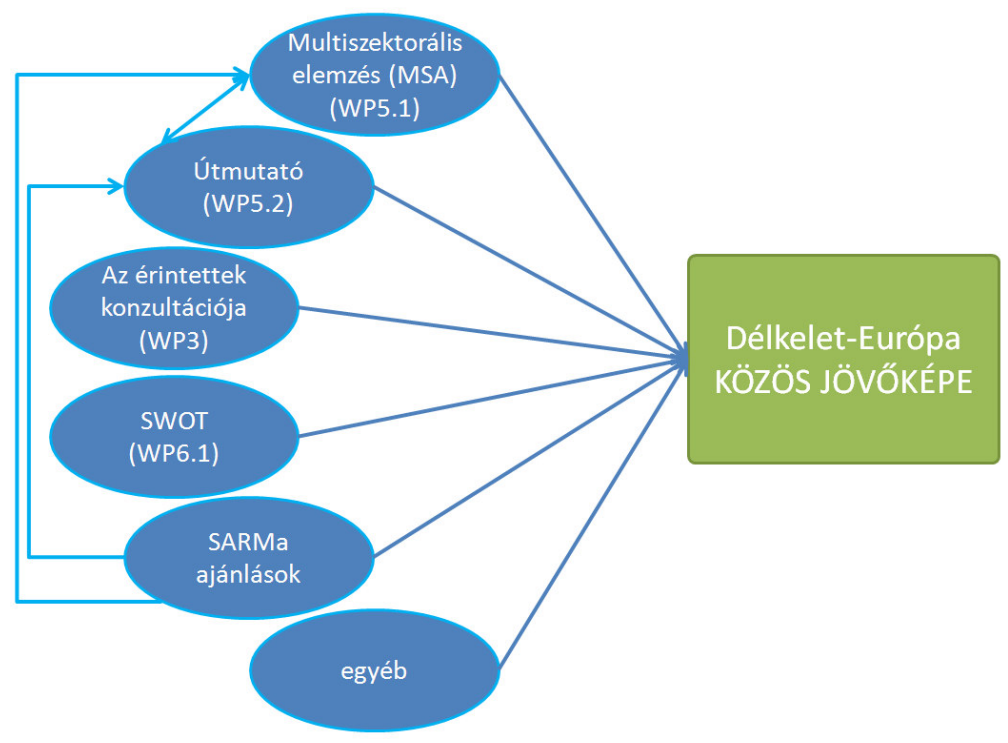

4.1. ábra: Délkelet-Európa közös jövőképének adatforrásai

A délkelet-európai országok az aggregátumtervezésének közös jövőképe a következő témákat foglalja magába: jogi-szabályozási keretek (országos szint, aggregátumtervezés, egyéb kapcsolódó politikák, engedélyezési eljárás, érdekelt felek bevonása, helyi tervezés, hatóságok, uniós vonatkozások), környezetvédelmi vonatkozások (légszennyezés, zaj, víz, bányászati bírságok és hulladék, ökológiai egyensúly), társadalmi vonatkozások (ismeretterjesztés és tudatosság), gazdasági vonatkozások (határon átnyúló SARM politika, adózás), szakmai feladatok (nyilvántartás, ásványvagyon-védelem), technológia (újrahasznosítás, robbantás, helyreállítás, biztonság) és általános (szállítás).

A szöveg kijelentő módban készült, jelezve, hogy a SEE országokban az elvégzendő feladatok -remélhetőleg- megvalósulnak körülbelül 2020-ig. Ezen időszak után a fenntartható aggregátumtervezés állapota az országos és uniós szabályozás változásaitól fog függeni. 


\subsection{Jogi-szabályozási keretek}

\subsubsection{Országos szint}

\section{Aggregátumtervezés}

Az aggregátum terv országos, regionális és helyi szinteken készül, és ez a szintek egymással összhangban vannak. Az országos tervezés általános megközelítés, míg a regionális és helyi tervek sokkal részletesebbek és nagyobb felbontásúak. Az aggregátumtervezési politika az egyéb politikákat (ásványvagyon-tervezési, fenntartható fejlődési, környezetvédelmi, hulladékgazdálkodási és újrafeldolgozási politikák) magába foglaló területrendezési politikán alapul. Az aggregátumtervezésnél az elsődleges és másodlagos aggregátumokat együtt kezelik az elsődleges aggregátumvagyon megóvása és a hulladéktermelés csökkentése érdekében. A helyi tervezésnél a másodlagos nyersanyagok részesedését az elsődleges anyagok kitermelésének mérlegelése előtt veszik figyelembe. A tervezést a tervezési hatóságok a különböző szektorok képviselőivel (tervezési hatóság, földtani és bányászati hatóságok, aggregátum-iparág, kormányzati szervek, országos környezet- és örökségvédelmi szervezetek) együttmüködve végzik. Az aggregátumtervezési politika kialakításakor nyilvános konzultációs eljárásba bevonják az érintett feleket. Mivel egyre nehezebben hozzáférhetőek az előfordulások, az aggregátumterveknek legalább 20 évre előre kell tekinteniük, valamint a közösség vagy társadalom igényeitől függően rendszeresen, pl. 5-10 évenként, frissíteni kell azokat. A kereslet-elörejelzés 10-15 évet vetít előre, és évenként felülvizsgálják a 10 éves átlagos eladási adatok mozgóátlagának és egyéb vonatkozó információk, valamint az ellátási lehetőségek (pl. másodlagos források) hatásvizsgálata alapján. Az aggregátumterv úgy készült, hogy megfeleljen ezeknek az igényeknek. Az engedélyezett készletek kielégítik legalább a következő 510 év igényeit. Az aggregátumtervezés figyelembe veszi a kereskedelmi/szállítási útvonalak optimalizációját és az aggregátumok életciklus-elemzését. $A z$ aggregátumkitermelést legtöbbször a nemzeti parkok, világörökségi és egyéb védett területek határain kívül végzik. Hatékony megfigyelő rendszerrel, magas büntetési tételekkel és az eladott aggregátumok eredet-megjelölésével megelőzhető az illegális bányászati tevékenység. Védett aggregátumterületeket jelölnek ki, hogy bizonyos helyi és országos fontosságú ásványvagyon ismert előfordulásai ne váljanak szükségtelenül meddővé egy nem bányászati célú fejlesztés miatt, de ez a kijelölés nem feltételezi, hogy az ásványvagyon kitermelésre kerül. Ezeken a területeken általában nem engedélyezik más tervek megvalósítását. A múvelt területet a lehető leghamarabbi időpontban, magas környezetvédelmi szabványoknak megfelelően, helyreállítják. Az aggregátumtervezés foglalkozik a helyreállítás költségeivel. Az aggregátumtervezési politika végrehajtását rendszeresen ellenőrzik. 
Minden SEE országban létezik minden, aggregátumokhoz kapcsolódó politika (fenntartható fejlődési politika, környezetvédelmi politika, ásványvagyon-gazdálkodási politika, hulladékgazdálkodási politika és területrendezési politika), hasonló fejlettségi szinten. Az ásványi nyersanyagokat, az aggregátumokkal együtt, egyenértékünek tekintik a többi természetes földi erőforrással. 2014-hez viszonyítva enyhültek a területhasználati korlátozások. A területrendezési tervek országos, regionális és helyi szinten készülnek. Tartalmaznak kitermelésre kijelölt területeket és védett ásványi nyersanyagkészleteket, tehát az ásványvagyon-tervezés a területrendezési terv részévé vált. Kötelező a fenntarthatóság szempontjának szürése. A Stratégiai Környezetvédelmi Hatásvizsgálatot (SEIA) az ásványvagyon-tervezést megelőző kiegészítő folyamatként végzik. A természetvédelmi területen történő bányászatot az Európai Bizottság 2010-ben elfogadott, erre vonatkozó útmutatója alapján szabályozzák. Ez a dokumentum ismerteteti, hogy hogyan kezelhetők összhangban az aggregátumkitermelési munkálatok és a biológiai sokféleség céljai. A területrendezési tervekben a jövőbeli aggregátumkitermelés figyelembe vételével kijelölték a földtani aggregátumvagyont a lelőhelyek más célú felhasználásnak elkerülése érdekében. A hulladékgazdálkodási politikák támogatják a bányászati hulladékok, építési és bontási hulladékok, építési munkálatok során kitermelt talajok és kőzetek, valamint ipari hulladékok újrahasznosítását. Nincs bürokratikus akadálya az újrafeldolgozásnak. Támogatják a hulladék átalakítását másodlagos nyersanyaggá; az építési és bontási hulladék legalább 70\%-át újrahasznosítják.

\section{Engedélyezési eljárás}

Az elsődleges aggregátumok bányászatának engedélyezési eljárása egyszerü, gyors és hatékony, amelyet egy fő szabályozó testület vezet. A bevont hatóságok hatékonyan múködnek együtt. „Egyablakos”modellt használnak, ami a leginkább ügyfélbarát megoldás. A hatékony engedélyezési rendszerek a fő piacok közelében hozzáférhetővé teszik a nyersanyagkészleteket, ezzel egyben optimalizálják a szállítási hatékonyságot, és minimalizálják a fogyasztók túlrendeléseit, valamint a hatékony végfelhasználói tervezéssel megszúntetik a veszteséget. Az eljárási határidőket egyértelmúen szabályozzák mind a hatóságok, mind az ügyfelek irányában. Megvalósult az érdekelt felek bevonása a folyamatba. E-ügyintézést alkalmaznak az eljárás folyamán, amely magában foglalja az e-jelentkezési lapokat, automatikus határidő figyelést, digitális dokumentációt. Mivel nagyméretű beruházásról van szó, a bányászati engedélyeket a mérettől függően jellemzően legalább 10-20 évre kell kiadni homok és kavics estén, és 20-50 évre kőfejtőknél. Az időfüggő progresszív pénzügyi szabályozási eszközök (pl. földhasználati díjak) elejét veszik a spekulációs földfoglalásnak. 


\section{Érdekelt felek bevonása}

Az eltérő földhasználat miatti konfliktusokat (pl. bányászat és védett területek) a résztvevő hatóságok, civil szervezetek, helyi közösségek és az iparágak közti konzultációval oldják meg. Az érdekelt feleket bevonják a tervezési folyamatba. A bányászati szektor együttmúködik a mezőgazdasági és környezetvédelmi hatóságokkal. A helyi közösségek részesülnek a bányajáradékból, így érdekeltek a kitermelésben.

\subsubsection{Regionális és helyi szint}

A regionális és helyi tervezési hatóságok a regionális és helyi kereslet alapján készített regionális és helyi tervekkel szintén részt vesznek a tervezésben. A helyi tervekhez helyi tájkép- és környezetvédelmi hatásvizsgálat készül. A tájképstratégiát és a helyreállítási terveket a terület felhagyás utáni felhasználását figyelembe véve, a kezdetektől fogva készítik. A helyi tervezési hatóság környezetvédelmi feltételrendszert állít fel, amivel biztosítja, hogy az engedélyezett múveleteknek nem lesz elfogadhatatlanul káros hatása a természeti és történelmi környezetre, vagy az emberi egészségre.

\subsubsection{Uniós vonatkozások}

Egységes közösségi aggregátumpolitikát dolgoznak ki, amely kiegyensúlyozottan veszi figyelembe a gazdasági, környezetvédelmi és társadalmi vonatkozásokat, hogy biztosítsa a fenntarthatósági gyakorlatot az aggregátum-iparág számára (Hámor, 2011). Naprakész jogi aggregátum terminológiát (elsődleges és másodlagos aggregátumokra) fogadtak el és használnak a tagállamokban. A termelésspecifikus, ökocímkéről és ökodíjról szóló trövénykezést kiterjesztik az elsődleges és másodlagos aggregátumtermelési rendszerekre. Műszaki útmutatókat készítenek a bányászati hulladékkezelés és az aggregátumkészletek összefüggésére vonatkozó előírásokról. A Natura 2000 hálózatra vonatkozó szabályokat egyformán alkalmazzák a különböző tagállamokban, így elkerülhető a piaci viszonyok torzulása, és a környezeti hatások határon túli kiterjesztése.

\subsection{Környezetvédelmi vonatkozások}

A közbeszerzések legtöbbször zöldek, újrafeldolgozott aggregátumot használnak. Az aggregátumiparág az aggregátumkitermelés idején az elérhető legjobb technológiák és ajánlott eljárások alkalmazásával foglalkozik a vízgazdálkodással, tájrendezéssel és talajgazdálkodással. A felhagyott kőfejtőket és bányagödröket használat után helyreállítják, vagy a helyi közösség számára hasznosítják. Az aggregátumkitermelő helyek hálózata támogatja a zöld infrastruktúra kialakítását, ún. „lépőköveket” 
(stepping stones) hoz létre a biológiai sokféleség számára. A Környezetvédelmi Hatásvizsgálat (EIA) folyamata egyszerüsödött, egyablakos eljárásként müködik, az EIA Irányelvben meghatározott eljárásokhoz jobban alkalmazkodva és időben történik. Jól múködik az EIA és egyéb uniós irányelvek és politikák, különösen a SEA (Stratégiai Környezetvédelmi Hatásvizsgálat) és az AA (Megfelelőségi Értékelés) közti koordináció.

\subsubsection{Légszennyezés}

A légszennyezés a határértékek alatt tartása érdekében intézkedések történtek a por- és gázkibocsájtás csökkentésére (portalanító rendszerekkel gyűjtik a finomszemcsés hulladékot, porelnyelő rendszereket alkalmaznak a porító üzemekben, lefedik szállító/aprító rendszereket és járműveket, nedvesen tartják az utakat és a bányaterületet). A por- és gázkibocsájtást rendszeresen ellenőrzik és értékelik.

\subsubsection{Zaj}

A zajszennyezés határértékek alatt tartása érdekében a szükségtelen zajt megszüntetik, a zajkibocsájtást csökkentik (pl. zajcsökkentő rendszerek használata, használaton kívüli gépek kikapcsolása, motorok felesleges használatának elkerülés, gumi burkolatok használata a csúszdákon, teherautókon, átrakodási pontokon, megfelelő robbantási technikák és anyagok használata, új utak építése a lakott területek elkerülése érdekében). Rendszeresen végeznek zajszintmérést, és az eredményeket összevetik az engedélyezett határértékkel és a területre jellemző környezetvédelmi elvekkel.

\subsubsection{Víz}

A felszín alatti vizek minőségének javítása érdekében számos intézkedéssel biztosítják a felelősségteljes és fenntartható vízgazdálkodást, pl. vízgazdálkodási terv (mind felszíni, mind felszín alatti vizekre vonatkozóan), víz-újrahasznosítás, és a bányatelekről történő szivárgások ellenőrzése. a felszín alatti vizek elszennyeződésének elkerülése érdekében vízminőség-védelmi eszközöket használnak (pl. vízálló geotextíliákkal takarják le a gépeket a karbantartási területen, vízelevezetési csatornákat hoznak létre a kitermelési területen). Mind a felszíni, mind a felszín alatti vizek minőségét ellenőrzik. Hidrogeológiai vizsgálatokkal követik nyomon a víz minőségének változását. A helyreállítási folyamat során a biológiai sokféleséget, árvízvédelmet, víztisztítást szolgáló ökoszisztéma számára tavakat és vízi élőhelyeket alakítanak ki.

\subsubsection{Bányászati hulladék}

A termelt hulladékot a bányamúvelés teljes életciklusa alatt kezelik. A bányászati hulladékot másodlagos aggregátumként vagy töltő anyagként hasznosítják tájépítésnél, kármentesítésnél. Ha a helyreállítás nem megoldható, a meddőhányókat lehető 
leghamarabb tájba illesztik és növényzetet telepítenek rájuk. A hulladékkezelési munkálatok a Hulladékkezelési Keretirányelvben megszabott rangsor szerint folynak: hulladéktermelés megelőzése, előkészítés újrahasznosításra, újrafeldolgozás, helyreállítás, és utolsó megoldásként ártalmatlanítás.

\subsubsection{Biodiverzitás és ökológiai ellensúlyok}

Az Európai Bizottság NEEl és Natura 2000-ről szóló Útmutatója (EC 2010a, 74. o.) szerint a biológiai sokféleség ellensúlyai „olyan mérhető megőrzési eredmények, amik olyan tevékenységek eredményeiként jönnek létre, amiket azért terveztek, hogy kiegyenlítsék azokat a biológiai sokszínűséget érintő káros hatásokat, amik a projekt tevékenységei során, a megfelelő védelmi és kárenyhítő intézkedések után lépnek fel. A biológiai sokszínűség ellensúlyainak célja, hogy ne érje a biológiai sokszínűséget nettó veszteség, és lehetőleg nettó nyereség jöjjön létre, azon az alapon, hogy tiszteletben tartják a fajok összetételét, az élőhely felépítését, az ökoszisztéma múködését és az emberek hasznát, valamint a biológiai sokszínűséghez kapcsolódó kulturális értékeket." A bányászati tevékenységnek mindig vannak nem várt környezeti/tájképi hatásai. Azonban a pénzügyi ellensúlyokkal vagy adózással ellentétben a helyreállítás a legjobb módszer az aggregátum-iparág számára, egy új biodiverzitás létrehozására a bolygatott területen. Egy terület helyreállítását a múködés és a végső helyreállítás során kárenyhítő intézkedésekkel és fokozatos helyreállítással érik el. A helyreállítást mindig előnyben kell részesíteni a biológiai sokféleség elvesztésének megállításánál, és az ellensúlyokat az elkerülhetetlen maradék hatások kompenzálásának végső megoldásaként kell figyelembe venni. A helyreállítást a tájhoz illesztve kell végrehajtani, figyelembe véve a biológiai, társadalmi és kulturális értékeket.

\subsubsection{Helyreállítás}

A helyreállítás előtt egy, a terület tervezett utóhasznosítását megjelölő, átfogó helyreállítási stratégiát készítenek. Ez információkat tartalmaz a talajról és a vízföldtani viszonyokról, valamint arról, hogy miként kell kezelni a kitermelés során a feltalaj/altalaj/fedőréteg/talajalkotó anyagokat; a terület mezőgazdásági besorolásának vizsgálatát; és a tájképstratégiát. A helyreállítás a bányászati múveletek megkezdésével indul, és végső helyreállítási terv szerint folyamatosan zajlik, ezáltal könnyebbé és hatékonyabbá válik a folyamat. A természetvédelmi és bányászati tevékenységek érdekeit kiegyensúlyozottan veszik figyelembe. A helyreállítási tervet a megvalósítás előtt egyeztetik a helyi érdekelt felekkel. A helyreállítási tervet előzetesen a bányatelek bezárása utáni a lehetséges felhasználási célokhoz igazítják (amennyiben azt meghatározták a helyi fejlesztési tervekben). Ahol a helyreállítási tervben földhasználati változtatás szerepel, új létesítmények, mint mély, vízzáró réteggel ellátott bányagödrök esetén tavak, sportlétesítmények, vagy pihenőparkok, vizes élőhelyek, jönnek létre. A természetes jellegzetességeket (pl.: patakok) helyreállítják, és még a bánya üzemideje alatt faiskolákat alakítanak ki, hogy helyi fajokkal támogassák a 
helyreállítási fázist. A károsodott földterület helyreállításához felhasználják vagy a bányászati múveletek kezdetén eltávolított és tárolt feltalajt, vagy a más területekről idehozott feltalajt. A maradandó szennyeződés keletkezését megelőzik.

\subsection{Társadalmi vonatkozások}

A SEE országokban az állam vagy önkéntes alapon az aggregátum cégek továbbfejlesztették és kifinomulttá tették a helyi közvélemény bevonását. Így az aggregátumkitermelés társadalmi elfogadottsága biztosítva van a tervezési szakasztól kezdődően. Ülések, workshopok, előadások, területrendezési térképek, hírlevelek, brosúrák és poszterek segítségével a helyi érdekelteket objektíven tájékoztatják és oktatják az elsődleges és másodlagos aggregátumokról. Mind a helyi tervezési hatóságok, mind az aggregátumcégek figyelembe veszik és tiszteletben tartják a helyi közösségek szükségleteit. A helyi közösségek tisztában vannak a helyi ásványvagyongazdálkodási tervekkel, az ásványi nyersanyagok hozzáférhetőségével és azok szükségességével. Az aggregátumcégek helyi munkaerőt alkalmaznak.

\subsection{Gazdasági vonatkozások}

A következetes ásványvagyon-gazdálkodási politikának köszönhetően a SEE országok importfüggősége csökkent mind az energetikai, mind a nem energetikai ásványi nyersanyagokra vonatkozóan, beleértve mind az elsődleges, mind másodlagos aggregátumokat. Emellett az EU javuló ellátási feltételekkel támogatja az aggregátumtermelést és -exportot, elkülönítve a nyersanyagbeszerzést és fejlesztve az erőforrás-hatékonyságot (beleértve az újrahasznosítást), valamint az alternatív nyersanyagok felhasználását. Az aggregátumgazdaság vizsgálata a Fenntartható Kínálati Mix (SSM) koncepción alapul. A bánya teljes életciklusát a kitermeléstől a feldolgozáson át a helyreállításig átfogóan tervezik meg.

\subsubsection{Határon átnyúló SARM politika}

A határon átnyúló aggregátumpiaci szerkezetek rendszeresen elemzik. A kereslet és kínálat (források), valamint a közép- és hosszú távú forgatókönyvek és a lehetséges kínálati opciók jól ismertek és közzé vannak téve. Az aggregátumkeresletet és kínálatot egyaránt befolyásolja a határon átnyúló SARM politika (aminek viszont piaci elemzéseken kell alapulnia). Határon túlnyúló SARM politikát alkalmaznak a SEE országokban, hogy kielégítsék a növekvő aggregátumigényt, különösen a határok közelében található nagyobb városok számára. A határokon átnyúló, út- és vasútépítésre vonatkozó nemzetközi pályázati keretrendszerben egyértelmúen meghatározzák az aggregátumok iránti igényt és a szállítási logisztikát. A legtöbb pénzügyi eszköz a nemzeti szuverenitás területén belül valósul meg. A kormányon múlik, hogy a nemzeti politika mentén kialakítsák ezeket a gazdásági hajtóerőket, azonban a pénzügyi 
eszközök jelentős eltérése torzított versenyhelyzethez vezethet a határ menti régiókban. A SEE országokban összehangolják a pénzügyi eszközöket. Fejlett az érdekelt felek közti adat- és tudáscsere, amely figyelembe veszi a transznacionális politikát. Rendszeresek az érdekeltek közti konzultációk, a legalább évente megrendezett találkozók hatékonyan múködnek. A SARM politikai keretrendszer megvalósul az országok közti európai szállítási hálózatnál: nemzetközi szinten veszik figyelembe az „aggregátumok és építkezés" közti kapcsolatot, beleillesztve ezt az ERDF célok és stratégiák közé.

\subsubsection{Adózás}

A C\&D hulladéklerakás adóztatása elősegíti, hogy a fogyasztás az elsődlegestől a másodlagos aggregátumok féle mozduljon el. Pénzügyi intézkedéseket segítségével támogatják az építési és bontási hulladékok újrahasznosítását. A hulladéklerakási adó elősegíti a hulladék minimalizálását és az újrahasznosítást. Az adóztatás célja az ipar és a fogyasztók ösztönzése arra, kevesebb hulladék termeljenek, csökkentsék a hulladéklerakást, minimalizálják a hulladék mennyiségét és beruházzanak egyéb típusú újrahasznosításokba és/vagy az erőforrások visszanyerésének területén. Aggregátumadó: a nemzetközi versenyképesség megóvása érdekében megadóztatják a behozatalt, de megkönnyítik a kivitelt. Az adó a bányászati múveletekhez kapcsolódó környezeti ártalmakra vonatkozik (zaj, por, vizuális behatás, kényelemvesztés, biodiverzitás károsodása), összhangban a kormány környezetvédelmi adókra vonatkozó szándékaival. Célja az elsődleges aggregátumok iránti igény csökkentése és az adómentes, újrafeldolgozott anyagok, valamint a másodlagos aggregátumok (pl. kaolin hulladék, pala hulladék, szénbányászati meddő) felhasználásának ösztönzése. Abból kiindulva, hogy az elsődleges anyagok kitermelésének és felhasználásának adóztatása nem a megfelelő eszköz az erőforráshatékonyság növelésére, pozitív ösztönző eszközök nagyban segítik az aggregátumiparágat.

\subsection{Szakmai feladatok}

\subsubsection{Nyilvántartás}

A SEE országokban létrehozták az elsődleges és másodlagos aggregátumok átfogó nyilvántartását, amely tartalmazza az inert bányászati, építési és bontási hulladékokat, vagy elérést biztosít hozzájuk. Az elsődleges aggregátumvagyon és készlet, illetve a termelési adatok átfogó nyilvántartása olyan térinformatikai adatokból áll, amely adatot szolgáltat a bányatelek alakjára és méretére, igazolt készletekre, valamint az aggregátumok típusaira és minőségére vonatkozóan. A másodlagos aggregátumok átfogó nyilvántartása információkat tartalmaz a műszaki jellemzőkről (típus, minőség, kezelési módszer stb.), elhelyezkedés, újrafeldolgozó üzemek, műszaki szabványok stb. A nyilvántartáshoz további személyzet és képzés finanszírozására van szükség. Az európai nyersanyagokra vonatkozó ismereteket összegyújtötték, és 
az összes érdekelt fél, azaz az érintett hatóságok, a nyersanyag- és feldolgozó ipar, kutatók és a társadalom, azonos cél érdekében dolgozik. Új, megbízható, az Unió ásványvagyon-potenciáljához kapcsolódó adatbázist építettek fel, hogy ellássák az európai tudásbázist elsődleges és másodlagos nyersanyagokra vonatkozó, harmonizált, szabványos adatokkal. A cél az Unió tudásbázisának javítása az Unió gazdasága és társadalma számára a fenntartható és biztonságos nyersanyagellátás fejlesztése, amely tartalmazza: (a) az uniós erőforrások (mind elsődleges, mind másodlagos aggregátumok) innovatív tudásbázisának kiépítése, és (b) a felsőoktatás minőségének és mennyiségének fejlesztése (képzett szakértők), kapcsolódva az uniós kutatáshoz és üzleti élethez a teljes nyersanyag-értékláncra vonatkozóan. Az elsődleges és másodlagos nyersanyagokhoz dinamikus modellezési rendszert fejlesztettek ki, és általánosan használják az aggregátumtervezésben. A nyilvántartások online, könnyen elérhető (vagy akár nyilvános) szolgáltatásokként működnek, amelyek információkat nyújtanak az aggregátumokról az összes országban a szükséges, mind elsődleges, mind másodlagos aggregátumkínálati (és keresleti) forrásokról. A szükséges szakmai hozzáértésre, meglévő adatbázisokra és szabályozási feladatokra alapozva a geológiai szolgálatok és a bányászati hatóságok intézik egy ilyen rendszer üzemeltetését. $A z$ adott országok egyéb hagyományai miatt jó az együttmúködés a geológiai szolgálatok és bányászati hatóságok, valamint regionális tervezési hatóságok és az állami környezetvédelmi intézmények között. Az országos minisztériumok elismerik a megbízhatóbb és teljesebb aggregátumstatisztikák jelentőségét.

\subsubsection{Földtan és aggregátumpotenciál}

A homok- és kavicselőfordulások értékelésének alapja a nem konszolidált üledékek térképe. Ez megmutatja mind a nem konszolidált üledékek földtani egységeinek regionális eloszlását, mind azok fácieseit, miközben információt nyújt az anyag legfontosabb kőzettani tulajdonságairól. A zúzott kő előfordulások és telepek földtani besorolása földtani térképek alapján történik. Figyelembe veszik a nyersanyag mennyiségét és minőségét, valamint az előfordulás jelentőségét a helyi vagy regionális ellátás szempontjából. Mindezen adatokat egy GIS alapú, online, mindenki számára hozzáférhető adatbázisba rendezik.

\subsection{3 Ásványvagyon-védelem}

$A z$ ásványvagyon védelmi területek (MSA) koncepcióját széles körben alkalmazzák. „Egy MSA jelenléte nem zárja ki egyéb tevékenységek engedélyezését a területen, és nem utal arra sem, hogy az ásványvagyon ki lesz termelve. Az MSA-k egyszerűen egy politikai eszközt jelentenek, amely figyelmeztet arra, hogy egy tervezett nem bányászati célú kivitelezés esetén az ásványvagyon elvesztésének lehetőségét figyelembe kell venni a tervezési folyamatnál..." (Wrighton et al. 2011, 1. o.). 


\subsection{Technológia}

Az aggregátum-iparág az elérhető legjobb technológiákat használja a leghatékonyabb kitermelés és a legmagasabb szintű zöld technológia biztosítása érdekében, ezzel minimalizálva az okozott lábnyomot, környezeti hatást, beleértve a vízfelhasználást, megőrizve és támogatva a biológiai sokszínűséget mind a múvelés alatt álló, mind a helyreállított bányatelkeken.

\subsection{1 Újrafeldolgozás}

A másodlagos nyersanyagokat, azaz a bányászati hulladékot, az építési és bontási hulladékot, az építési munkálatok során kitermelt földet és kőzeteket, valamint az ipari hulladékot, aggregátumként hasznosítják. Az építési és bontási (C\&D) hulladékot az EK 2008/98 sz. Irányelve alapján legalább 70\%-ban újrahasznosítják. A C\&D hulladék újrahasznosítása fontos lehetőségeket teremt: csökkenti a hulladéklerakáshoz szükséges területigényt (i), gátolja a természetes, nem megújuló aggregátumkészletek túlfogyasztását azáltal, hogy alternatív és kiegészítő anyagokat vezet be az aggregátumpiacra (ii), új üzleti lehetőségeket teremt a hulladékhasznosítás számára (iii). A C\&D hulladékot előzetesen a keletkezés helyén homogén részekre osztják. Ez a szelektív bontás csökkenti az újrahasznosítási vagy ártalmatlanítási (ahol előfordul) költségeket és jobb minőségű újrafeldolgozott termékeket biztosít. Az újrafeldolgozott aggregátumokat széles körben használják az infrastrukturális beruházások kötőanyag nélküli alkalmazásainál (út és vasút alapozások), környezeti helyreállításoknál és kis szilárdságú beton keverékeknél. Az aggregátum kiválasztása egy bizonyos alkalmazáshoz csak annak anyagi tulajdonságain, és nem az eredetén múlik. Az európai múszaki szabványok nem tesznek különbséget az aggregátumok közt az eredetük, csak kizárólag azok tulajdonságai alapján. Így az uralkodó európai normáknak és előírásoknak megfelelő, CE jelölű újrafeldolgozott aggregátumtermékek felveszik a versenyt a hagyományos aggregátumokkal. A természetes és újrafeldolgozott aggregátumok közös használata a természeti erőforrások elvárt védelme mellett lehetővé teszi az elérhető erőforrások jobb kihasználását a különböző felhasználási célok számára.

\subsubsection{Robbantás}

Az aggregátumipar szakaszos robbantást és modern technológiát alkalmaz a vibráció és a zaj csökkentése érdekében, amiket ellenőriznek. Amennyiben a természeti körülmények megengedik, a robbantást elkerülik.

\subsubsection{Biztonság}

Az aggregátum vállalkozások figyelmet szentelnek az egészség és biztonság témakörnek, a halálesetek, sérülések megelőzésével és egészséges munkakörnyezettel a Zéró Sérülésre összpontosítanak. Ehhez nem csak teljesen hozzáértő munkaerő szükséges, 
hanem az ellátási lánc minden elemének összehangoltan kell dolgoznia biztosítva, hogy az alkalmazottak a SAFER BY DESIGN útmutatásnak megfelelő gépekkel és berendezésekkel végezzék a feladatukat.

\subsection{Szállítás}

A maximális szállítási hatékonyság a vízi és vasúti hálózatok stratégiai tervezésével megvalósult, így ezekkel az eszközökkel több aggregátumot szállítanak. Az országos aggregátumtervezési politikák össze vannak hangolva a vízi és vasúti szállítási fejlesztési stratégiákkal, ezzel biztosítják a kormányzat, az aggregátum-iparág, szállítmányozók és társadalom számára az optimális ellátási és szállítási megoldásokat. A közúti szállítást a piacok lehető legközelebbi erőforrások hozzáférhetőségének növélésével optimalizálták. A szállítási távolságokat a helyi erőforrások felhasználásával csökkentik. Ezzel továbbá minimalizálják a járulékos $\mathrm{CO}_{2}$-kibocsátást és az energiafogyasztást, valamint csökkentik a környezeti hatásokat és a forgalmi leterhelést. A nagyobb méretű szállítójármúvek alkalmazásával tovább csökken a tehergépjármű forgalom, üzemanyag-felhasználás és $\mathrm{CO}_{2}$-kibocsátás. A homok és kavics 30 km-nél messzebb történő szállításának költsége megnöveli a nyersanyag értékét, így a szállítási költséghatékonyságot a helyi aggregátumforrások felhasználásával érték el.

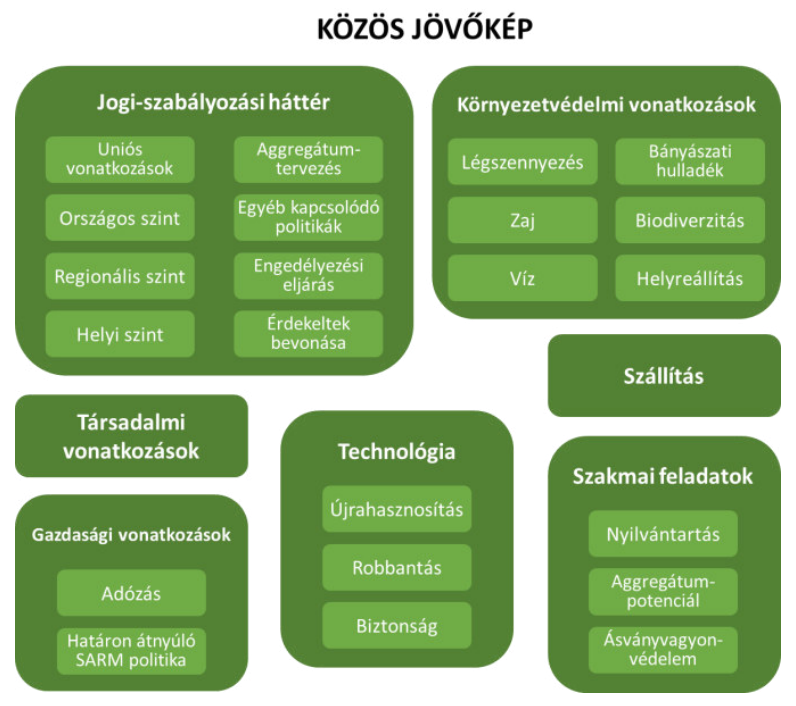

4.2. ábra: A Közös Jövőkép témakörei 


\section{Javaslatok az aggregátumtervezés ajánlott eljárásaihoz}

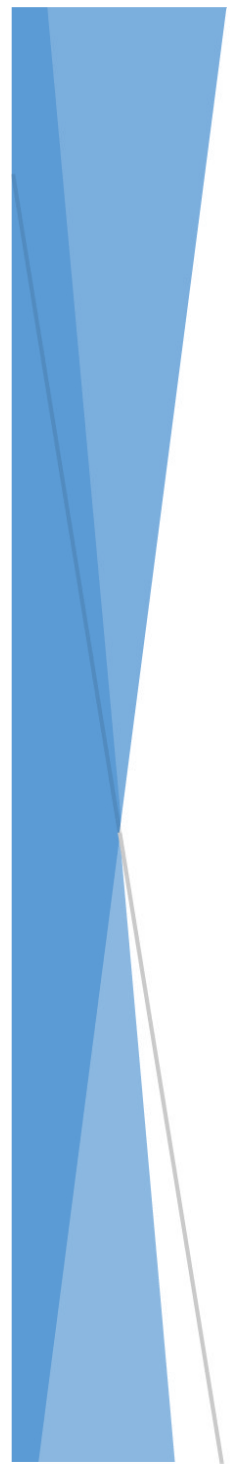

Összefoglalásként összegyüjtöttük az egyes fejezetek ajánlásait. Ezek a legfontosabb állítások, amelyeket figyelembe kell venni egy átfogó és integrált aggregátumtervezés megkezdésekor vagy végrehajtásakor.

Az ajánlások a multiszektorális elemzés eredményein, $a z$ aggregátumtervezés néhány ajánlott eljárásán és a SNAPSEE projekt partereinek, többek közt az általuk tartott konzultációkon szerzett, tapasztalatain alapulnak. Arra ösztönözzük az olvasót, hogy terjessze ezt a kézikönyvet, és vegye figyelembe a jól bevált lépéseket egy fenntartható délkelet-európai aggregátumtervezés kialakitása érdekében. 


\section{Aggregátumtervezés}

$\checkmark \quad$ Az aggregátumtervezési politikára a fenntartható aggregátumellátás biztosításához van szükség. Ebben a tervezési politikában együttesen kell kezelni az elsődleges és másodlagos aggregátumokat annak érdekében, hogy megóvjuk az elsődleges aggregátumvagyont, csökkentsük a bányászati és C\&D hulladék, valamint az ipari melléktermékek mennyiségét. Az aggregátumokhoz való hozzáférés biztosítása érdekében az aggregátumterveknek legalább 20 évre előre kell tekinteniük, és legalább 5-10 évenként frissíteni kell azokat.

$\checkmark \quad$ Az aggregátumtervezést országos, regionális és helyi szinten kell megvalósítani. Az országos tervezés egy általános megközelítés, míg a regionális és helyi tervek részletesek.

$\checkmark$ Az aggregátumtervezési politika kialakítása során be kell vonni a megfelelő érdekelt feleket, így a politika egy nyilvános konzultációs eljáráson megy keresztül.

\section{Engedélyezési eljárás}

Az elsődleges aggregátumok kitermelésének engedélyezési eljárása legyen egyszerű, gyors és hatékony, amelyet egy fő szabályozó szervezet irányít. Az „egyablakos” modell a leginkább ügyfélbarát megoldás, amely nagyon hatékonyan múködhet a közigazgatási bürokráciában. Mivel nagyértékű beruházások történnek, a bányászati engedélyeket jellemzően 10-20 évre kell megadni homok és kavics kitermelés, 20-50 évre kőbányászat esetén.

\section{Társadalmi vonatkozások}

$\checkmark \quad$ Az államnak vagy önkéntes alapon a bányavállalkozóknak biztosítania kell a helyi társadalom erőteljes és kifinomult bevonását a SEE országokban.

$\checkmark$ A különböző földhasználati konfliktusokat az érdekelt felek (pl. döntéshozók, környezetvédelmi hatóságok, bányászati iparág, civil szervezetek) közti konzultációval kell feloldani.

\section{Környezetvédelmi vonatkozások}

$\checkmark$ A Natura 2000 keretrendszert egységesen kell alkalmazni a különböző tagországokban, hogy elkerülhetők legyenek a piaci feltételek torzulásai és a környezetvédelmi hatások országhatáron túli exportja.

$\checkmark \quad$ Az aggregátum-iparágnak a kitermelés során az elérhető legjobb technológiák alkalmazásával és az ajánlott eljárások követésével foglalkoznia kell a vízgazdálkodással, tájépítéssel és talajgazdálkodással. 


\section{Hivatkozások}

Bressi, G., Volpe, G., Pavesi, E. (2011). The production of recycled aggregates. SARMa Manual.

Chalkiopoulou, F., Hatzilazaridou, K. (2011). How to Achieve Aggregates Resource Efficiency in Local Communities. SARMa Manual.

Chalkiopoulou, F., Hatzilazaridou, K. (2013). How is Planning currently being carried out in Greece? SNAP-SEE project, www.snapsee.eu (WP5.1 report)

Cibin et al. (2011). Providing a Sustainable Supply Mix of Aggregates: State-of-the-art in South-East Europe.

Department for Communities and Local Government (2012). 'National Planning Policy Framework' (www.communities.gov.uk).

Department for Communities and Local Government (2014). 'Planning Practice Guidance' (http://planningguidance.planningportal.gov.uk).

European Commission (2010a). EC Guidance on undertaking new non-energy extractive activities in accordance with Natura 2000 requirements

European Commission (EC), DG Enterprise and Industry (2010b): Abridged report of the ad-hoc Working Group on Exchanging Best Practice on Land Use Planning, Permitting and Geological Knowledge Sharing

Hámor, T. (2004). Sustainable mining in the European Union: The legislative aspect Environmental Management, Vol. 33., pp. 252-261.

Hámor, T. (2011). Synthesis report on legislation and regulatory framework related to sustainable aggregate resources management in selected South East European Countries - SARMA project, Budapest, $156 \mathrm{p}$.

Hámor, T., Tiess, G., Kager, J., Heimburg, J. (2011). European Community law relevant to aggregates - SARMA project, Budapest, $46 \mathrm{p}$.

Hicks, L. (2008). Aggregates supply in England. Issues for planning. - British Geological Survey Open Report, OR/08/059. 24 pp.

Horváth, Z., Sári, K. (2013). How is Planning currently being carried out in Hungary? SNAP-SEE project, www.snapsee.eu (WP5.1 report)

Horváth, Z., Sári, K. (2014a). Multi-sectoral Analysis of State of Planning Aggregates. SNAP-SEE project, www.snapsee.eu (WP5.1 report) 
Horváth, Z., Sári, K., (2014b). Guidance for Aggregates Planning Questionnaire for Hungary, SNAP-SEE project, www.snapsee.eu (WP5.2 report)

Janova, V., Fabian, M., Mesarcik, I. (2013). How is Planning currently being carried out in Slovakia? SNAP-SEE project, www.snapsee.eu (WP5.1 report)

Maruntiu, M., Coltoi, O., Marica, S. (2013). How is Planning currently being carried out in Romania? SNAP-SEE project, www.snapsee.eu (WP5.1 report)

Maruntiu, M., Marica, S., Coltoi, O., (2014). Guidance for Aggregates Planning Questionnaire for Romania, SNAP-SEE project, www.snapsee.eu (WP5.2 report)

Mati, S., Moisiu, L., Avxhi, A. SH.GJ.SH (2013). How is Planning currently being carried out in Albania? SNAP-SEE project, www.snapsee.eu (WP5.1 report)

Miko, S., Kruk, B., Dedić, Ž., Kovačević Galović, E., Hasan, O. (2013). How is Planning currently being carried out in Croatia? SNAP-SEE project, www.snapsee.eu (WP5.1 report)

Miko, S., Kruk, B., Dedić, Ž., Kovačević Galović, E., Hasan, O., (2014a). Guidance for Aggregates Planning Questionnaire for Croatia, SNAP-SEE project, www.snapsee.eu (WP5.2 report)

Miko, S., Kruk, B., Dedić, Ž., Kovačević Galović, E., Hasan, O. (2014b). Guidance on Aggregates Planning in South East Europe. SNAP-SEE project, www.snapsee.eu (WP5.2 report)

Miletić, S., Žibret, G., Burger, A. (2013). How is Planning currently being carried out in Slovenia? SNAP-SEE project, www.snapsee.eu (WP5.1 report)

Miletić, S., Žibret, G., Senegačnik, A., Rokavec, D., (2014). Guidance for Aggregates Planning Questionnaire for Slovenia, SNAP-SEE project, www.snapsee.eu (WP5.2 report)

Moisiu, L., Mati, S. (2014). Guidance for Aggregates Planning Questionnaire for Albania, SNAP-SEE project, www.snapsee.eu (WP5.2 report)

Moltrer, A., Valbusa, M. (2013). How is Planning currently being carried out in Autonomous Province of Trento (Italy)? SNAP-SEE project, www.snapsee.eu (WP5.1 report)

Moltrer, A., Valbusa, M. (2014). Guidance for Aggregates Planning Questionnaire for Trento - Italy, SNAP-SEE project, www.snapsee.eu (WP5.2 report)

Ontario Ministry of Natural Resources (2010). The State of the Aggregate Resource in Ontario Study. Consolidated Report

(http://www.mnr.gov.on.ca/stdprodconsume/groups/lr/@mnr/@aggregates/do cuments/document/286996.pdf) 
Poulin, R., Bilodeau, M.L. (1993). A model of a mineral aggregate market: The Eastern Coastal USA. Resources Policy, Volume 19, Issue 2.

Radusinovic, S., Čović, R., Asanović, D. (2013). How is Planning currently being carried out in Montenegro? SNAP-SEE project, www.snapsee.eu (WP5.1 report)

Rizzati, A., Romagnoli, M., Marasmi, C. (2013). How is Planning currently being carried out in Emilia-Romagna Region? SNAP-SEE project, www.snapsee.eu (WP5.1 report)

SARMa Glossary, http://www.sarmaproject.eu/index.php?id=1904

Shields, D.J., Solar, S.V. (2006). The nature and evolution of mineral supply choices. In: Cardu, M., Ciccu, R., Lovera, E. and Michelotti E. Proceedings of the 15th International Symposium on Mine Planning and Equipment Selection, September 20-22, 2006, Torino, IT. Galliate, IT: FIORDO, pp. 902-907.

Shields, D.J. (2013). Planning for Aggregates in the United Kingdom and Canada: strengths and weaknesses. SNAP-SEE project, www.snapsee.eu (WP6.1 report)

Simić V., Životić D., Andrić N., Miladinović Z. (2013). How is Planning currently being carried out in Serbia? SNAP-SEE project, www.snapsee.eu (WP5.1 report)

Simić, V., Životić, D., Andrić, N., Miladinović, Z., (2014). Guidance for Aggregates Planning Questionnaire for Serbia, SNAP-SEE project, www.snapsee.eu (WP5.2 report)

Strategic Implementation Plan For The European Innovation Partnership On Raw Materials (2013).

Susa, I., Broceta, V. (2013). How is Planning currently being carried out in Herzegbosnian Canton (Bosnia and Herzegovina)? SNAP-SEE project, www.snapsee.eu (WP5.1 report)

Suša, I., Broćeta, V., Kaselj, R., (2014). Guidance for Aggregates Planning Questionnaire for Herzegbosnian Canton (Bosnia and Herzegovina), SNAP-SEE project, www.snapsee.eu (WP5.2 report)

Tiess, G. (2010): Planning Policies and Permitting Procedures to Ensure the Sustainable Supply of Aggregates in Europe, Final Report, Leoben, 53. p.

Tiess, G. (2011): General and International Mineral Policy, Springer ISBN 978-3-211$89004-2,630 \mathrm{p}$.

Tiess, G., Chalkiopoulou, F. (2011). Sustainable Aggregates Resource Management and Sustainable Supply Mix at the Regional, National and Transnational Level. SARMa Manual. $61 \mathrm{p}$. 
Tiess, G. (2013). How is Planning currently being carried out in Austria? SNAP-SEE project, www.snapsee.eu (WP5.1 report)

Tiess, G. (2014). Guidance for Aggregates Planning Questionnaire for Austria; SNAPSEE project, www.snapsee.eu (WP5.2 report)

UEPG Position Paper: UEPG Key Messages on the EU Roadmap: Towards a resourceefficient Europe. www.uepg.eu

UEPG Position Paper: UEPG Sustainable Transport Policy. www.uepg.eu

UEPG Position Paper: Safer by Design. www.uepg.eu

UEPG Position Paper: Land Use and the Aggregates Industry. www.uepg.eu

UEPG Position Paper: UEPG Position on Resource Taxation. www.uepg.eu

UEPG Position Paper on Ecological Offsets. www.uepg.eu

UEPG Position Paper: Water Management in the Aggregates Industry. www.uepg.eu

Wrighton, C.E., McEvoy, F.M. and R. Bust (2011). Mineral Safeguarding in England: good practices advice. British Geological Survey Open Report OR/11/046. 53p. 



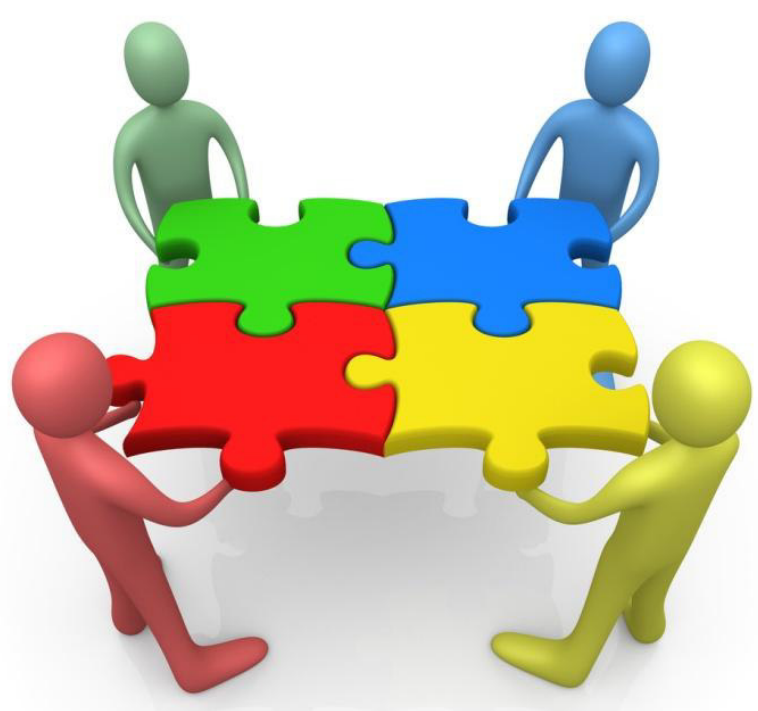

Fenntartható Aggregátumtervezés Délkelet-Európában (SNAP-SEE)

http://www.snapsee.eu 